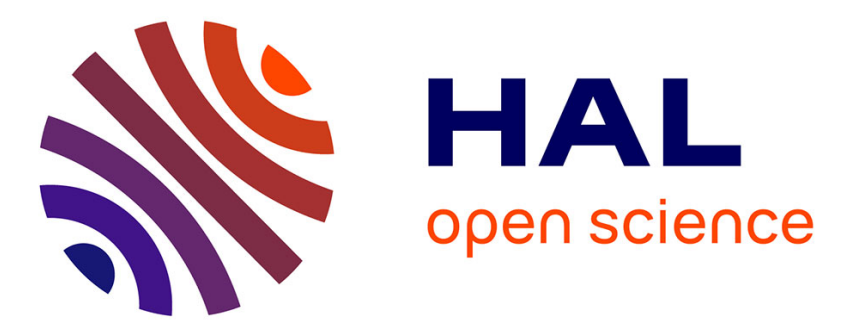

\title{
Myostatin up-regulation is associated with the skeletal muscle response to hypoxic stimuli
}

Maurice Hayot, Julie Rodriguez, Barbara Vernus, Gilles Carnac, Elise Jean, David Allen, Lucie Goret, Philippe Obert, Robin Candau, Anne Bonnieu

\section{- To cite this version:}

Maurice Hayot, Julie Rodriguez, Barbara Vernus, Gilles Carnac, Elise Jean, et al.. Myostatin upregulation is associated with the skeletal muscle response to hypoxic stimuli. Molecular and Cellular Endocrinology, 2010, 332 (1-2), pp.38. 10.1016/j.mce.2010.09.008 . hal-00654970

\section{HAL Id: hal-00654970 \\ https://hal.science/hal-00654970}

Submitted on 24 Dec 2011

HAL is a multi-disciplinary open access archive for the deposit and dissemination of scientific research documents, whether they are published or not. The documents may come from teaching and research institutions in France or abroad, or from public or private research centers.
L'archive ouverte pluridisciplinaire HAL, est destinée au dépôt et à la diffusion de documents scientifiques de niveau recherche, publiés ou non, émanant des établissements d'enseignement et de recherche français ou étrangers, des laboratoires publics ou privés. 


\section{Accepted Manuscript}

Title: Myostatin up-regulation is associated with the skeletal muscle response to hypoxic stimuli

Authors: Maurice Hayot, Julie Rodriguez, Barbara Vernus, Gilles Carnac, Elise Jean, David Allen, Lucie Goret, Philippe Obert, Robin Candau, Anne Bonnieu

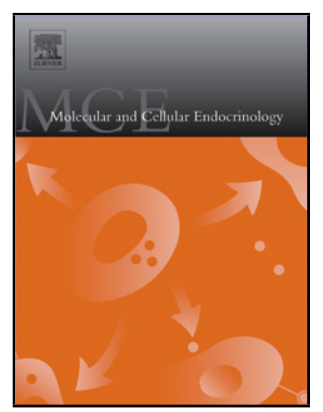

PII: S0303-7207(10)00469-7

DOI: doi:10.1016/j.mce.2010.09.008

Reference: MCE 7639

To appear in: Molecular and Cellular Endocrinology

Received date:

$17-4-2010$

Revised date: $16-9-2010$

Accepted date: $16-9-2010$

Please cite this article as: Hayot, M., Rodriguez, J., Vernus, B., Carnac, G., Jean, E., Allen, D., Goret, L., Obert, P., Candau, R., Bonnieu, A., Myostatin up-regulation is associated with the skeletal muscle response to hypoxic stimuli, Molecular and Cellular Endocrinology (2010), doi:10.1016/j.mce.2010.09.008

This is a PDF file of an unedited manuscript that has been accepted for publication. As a service to our customers we are providing this early version of the manuscript. The manuscript will undergo copyediting, typesetting, and review of the resulting proof before it is published in its final form. Please note that during the production process errors may be discovered which could affect the content, and all legal disclaimers that apply to the journal pertain. 
Myostatin up-regulation is associated with the skeletal muscle response to

\section{hypoxic stimuli}

Maurice Hayot ${ }^{2,3 \S}$, Julie Rodriguez ${ }^{1 \S}$, Barbara Vernus ${ }^{1}$, Gilles Carnac ${ }^{2}$, Elise Jean ${ }^{2}$,

David Allen ${ }^{4}$, Lucie Goret ${ }^{5,6}$, Philippe Obert ${ }^{5}$, Robin Candau ${ }^{1}$, and Anne Bonnieu ${ }^{*}$.

(1) INRA, UMR866 Différenciation Cellulaire et Croissance, Université Montpellier 1, F34060 Montpellier

(2) INSERM, ERI 25-Muscle et Pathologies, Hôpital Arnaud de Villeneuve, Bât. A Craste de Paulet, F-34295 Montpellier

(3) CHU Montpellier, Service Central de Physiologie Clinique, Hôpital Arnaud de Villeneuve, F-34295 Montpellier

(4) Department of Integrative Physiology, University of Colorado, Boulder, Colorado

(5) EA4278, Research Laboratory: 'Physiology and Pathophysiology of Cardiovascular Adaptations to Exercise' - Avignon University, Avignon, France

(6) EA2992, Research laboratory: 'Dynamics of Cardiovascular Incoherences', Montpellier Nimes University - F-30000 Nimes

$\S$ These authors contributed equally to this work.

*Correspondence to:

Dr A. Bonnieu

INRA, UMR 866-Différenciation Cellulaire et Croissance

Place Viala

34060 Montpellier Cedex 1

France

Phone: (33) 499612817

Fax: (33) 467545694

bonnieu@supagro.inra.fr 


\begin{abstract}
Myostatin and hypoxia signalling pathways are able to induce skeletal muscle atrophy, but whether a relationship between these two pathways exists is currently unknown. Here, we tested the hypothesis that a potential mechanism for hypoxia effect on skeletal muscle may be through regulation of myostatin. We reported an induction of myostatin expression in muscles of rats exposed to chronic hypoxia. Interestingly, we also demonstrated increased skeletal muscle myostatin protein expression in skeletal muscle of hypoxemic patients with severe chronic obstructive pulmonary disease (COPD). Parallel studies in human skeletal muscle cell cultures showed that induction of myostatin expression in myotubes treated with hypoxiamimicking agent such as cobalt chloride $\left(\mathrm{CoCl}_{2}\right)$ is associated with myotube atrophy. Furthermore, we demonstrated that inhibition of myostatin by means of genetic deletion of myostatin or treatment with blocking antimyostatin antibodies inhibits the $\mathrm{CoCl}_{2}$-induced atrophy in muscle cells. Finally, addition of recombinant myostatin restored the $\mathrm{CoCl}_{2}$ induced atrophy in myostatin deficient myotubes. These results strongly suggest that myostatin can play an essential role in the adaptation of skeletal muscle to hypoxic environment.
\end{abstract}

Keywords : hypoxic stimulus, myostatin, skeletal muscle atrophy, COPD, myotubes 


\section{Introduction}

Myostatin, a member of the TGF $\beta$ superfamily of ligands, has been shown to be a negative regulator of skeletal muscle mass during embryogenesis and early postnatal muscle growth (Kambadur et al., 1997; McPherron et al., 1997). In mice, inactivation of myostatin leads to robust muscle growth resulting from a combination of muscle cell hyperplasia and hypertrophy. Subsequently, naturally inactivating mutations in the myostatin gene have been demonstrated to cause increased muscling in cattle, sheep, dogs and humans suggesting that the function of myostatin is conserved -across species (Clop et al., 2006; Grobet et al., 1997; Kambadur et al., 1997; McPherron et al., 1997; Mosher et al., 2007; Schuelke et al., 2004). More recently, data have demonstrated that myostatin negatively regulates muscle mass not only during early embryogenesis but later during adult muscle growth (Grobet et al., 2003; Whittemore et al., 2003). In line with these findings, is the discovery that myostatin can inhibit the activation and self renewal of satellite cells (McCroskery et al., 2003) which are adult stem cells resident in skeletal muscle, responsible for postnatal muscle cell growth and new muscle protein production (Moss and Leblond, 1971).

Several studies indicate that myostatin is an important mediator of muscle atrophy. For example, administration of myostatin in vivo to adult mice induces profound muscle loss analogous to that seen in human cachexia syndromes (Zimmers et al., 2002). A decrease in muscle mass has been reported in transgenic mice overexpressing myostatin in skeletal muscle (Reisz-Porszasz et al., 2003). Similarly, ectopic expression of myostatin through gene electrotransfer of a myostatin expression vector induces atrophy of skeletal adult muscle associated with decreased muscle gene expression (Durieux et al., 2007). Myostatin expression also appears to be sensitive to atrophic and/or hypertrophic signalling. For example, the anabolic agent growth hormone $(\mathrm{GH})$ decreased myostatin expression in muscles of $\mathrm{GH}-$ 
deficient adults (Liu et al., 2003) and androgens negatively regulate myostatin expression in an androgen-dependent skeletal muscle (Mendler et al., 2007). In contrast, increased myostatin expression has been observed in several atrophic states, including prolonged bed rest in young men (Zachwieja et al., 1999), chronic disuse atrophy in older patients (Reardon et al., 2001) and age-related muscle wasting (sarcopenia) (Yarasheski et al., 2002). Despite this progress in our understanding of the role of myostatin in muscle atrophy, it is not currently known how myostatin is connected with atrophic signalling pathways.

Evidence has strongly suggested that hypoxia can also induce muscle atrophy. Hypoxia can be caused by a generalized reduction in oxygen delivery, such as altitude and pulmonary diseases, or by disruption in the local blood supply, such as an ischemic disorder. It is known that chronic exposure to high-altitude hypoxia (Hoppeler et al., 1990; Howald and Hoppeler, 2003; MacDougall et al., 1991) can cause a reduction of muscle fibre size and loss of skeletal muscle mass in mountaineers. Similar findings have been reported in healthy people who live at high altitude for generations and in rats chronically exposed to a simulated hypobaric altitude (Sillau and Banchero, 1977). In addition, the decrease in muscle mass at high altitude is associated with an anorexic effect. However, even when the anorexic effect is controlled using pair feed experimental design the decrease in muscle mass is observed indicating that part of hypoxia-induced skeletal muscle atrophy is independent of undernutrition associated with hypoxia (Bigard et al., 1996; Favier et al., 2010; Pison et al., 1998). Chronic obstructive pulmonary disease (COPD) is characterized by airflow limitation. During the past ten years, COPD has emerged as a multi-organ-system disease (Wouters, 2004). Besides primary effects in the lung, COPD as a chronic disease has secondary effects on other systems including skeletal muscle. Specifically, COPD is characterized by skeletal muscle dysfunction and atrophy (Agusti et al., 2003; Wouters, 2005). Chronic hypoxaemia, a common physiopathological consequence of COPD, has been proposed as a potential contributor, 
among others, of peripheral muscle dysfunction in this disease (Couillard and Prefaut, 2005; Gosker et al., 2002). However, the exact mechanisms underlying skeletal muscle dysfunction in COPD remain unclear. Understanding the mechanisms underlying the muscle response to hypoxia may provide insights into how muscle mass is regulated both in physiological and pathological situations.

Taking into consideration the importance of hypoxia and myostatin in skeletal muscle atrophy, we hypothesized that the muscle hypoxia effects might involve an up-regulation of myostatin gene expression. The aims of this study were first to characterize myostatin levels in skeletal muscles of rats exposed to hypobaric hypoxia and in skeletal muscles of hypoxemic COPD patients. We then investigated whether myostatin is required for the action of cobalt chloride (a hypoxic mimetic agent) in skeletal muscle cells.

\section{Materials and Methods}

\subsection{Animals}

Ten-week-old Wistar male rats (Harlan laboratories, France; n=30) were randomly assigned into 3 groups. Hypoxic animals (H rats, $\mathrm{n}=10)$ lived continuously for 5 weeks in hypobaric hypoxia (barometric pressure $\approx 475 \mathrm{~mm} \mathrm{Hg} ; \mathrm{PIO}_{2} \approx 90 \mathrm{~mm} \mathrm{Hg}$, altitude $\approx 4500 \mathrm{~m}$ ). The two other groups of rats were maintained in normoxia (barometric pressure $\approx 760 \mathrm{~mm}$ $\mathrm{Hg} ; \mathrm{PIO}_{2} \approx 159 \mathrm{~mm} \mathrm{Hg}$, altitude $\approx 80 \mathrm{~m}, \mathrm{~N}$ rats). The corresponding environments were created in steel chambers with a vacuum pump as previously described (Goret et al., 2005). Hypoxic rats $(\mathrm{H})$ and normoxic rats $(\mathrm{N})$ were fed ad libitum. Because of hypoxic impact on food intake and consequently on animal growth, a pair feed model was applied to normoxic rats (Npf) as previously described (Bigard et al., 1996). Thus, the pair fed animals (Npf) were restricted to have the same food intake than the $\mathrm{H}$ rats. 
All procedures were performed according to the Guide for the Care and Use of Laboratory Animals published by the US National Institutes of Health (NIH Publications No. 85-23, revised 1996) and with the approval of the French Ministry of Agriculture.

\subsection{Study population}

\subsubsection{COPD patients and Healthy control subjects}

The study population consisted of 10 patients with clinically diagnosed very severe COPD as defined by the American Thoracic Society (ATS) and European Respiratory Society (ERS) (Nici et al., 2006) and by the "Global Initiative for Chronic Obstructive Lung Disease (GOLD) and a group of healthy sedentary age-matched controls. All patients suffered from chronic airflow limitation, defined as a measured Forced expiratory volume in 1 second (FEV1)/Forced vital capacity $($ FVC) $<60 \%$ of predicted values. They were under long term oxygen therapy for at least the last 6 months before the study. This group of patients showed low hypoxemia at rest with a mean value of $\mathrm{PaO}_{2}=64 \pm 2 \mathrm{~mm} \mathrm{Hg}$. At the time of the study, patients were in stable clinical state, i.e. no clinical exacerbation during the last 4 weeks. All had sedentary way of life as confirmed by the Voorrips et al. questionnaire score $<9$ (Voorrips et al., 1991) and had not been enrolled in a pulmonary rehabilitation in the last year. Five healthy sedentary control subjects, volunteered to participate in the study, were non smokers and had no history or physical examination of lung or heart disease. They also had a low level of physical activity (Voorrips score <9). Exclusion criteria were no other potentially confounding factors such as neuromuscular disease, chronic heart failure, renal diseases, and liver diseases. No patient was on anticoagulant medication. Informed written consent was obtained from all patients, and the research protocol was approved by the institutional ethics committee of Montpellier Hospital and conducted in accordance with the Helsinki declaration and the European guidelines for "good clinical practice". 


\subsubsection{Muscle exercise tests}

6 minutes walk test (6-MWT): A 6-MWT was conducted according to a standardized protocol (2002).

Localized muscle function tests: The maximal voluntary contraction (MVC) and endurance of the quadriceps were assessed on an exercise bench according to the technique previously described by our group (Delample et al., 2008).

\subsubsection{Muscle biopsy of the vastus lateralis}

Muscle biopsy procedures: A percutaneous muscle biopsy of the vastus lateralis muscle of the dominant leg was performed in each subject, at mid-thigh $(15 \mathrm{~cm}$ above the patella) as described (Bergstrom, 1975) and often used by our group (Hayot et al., 2005). The specimens were immediately frozen in isopentane cooled to freezing point with liquid nitrogen and stored at $-80^{\circ} \mathrm{C}$ until analysis.

\subsubsection{Assessment of body composition}

Fat mass and fat-free mass (FFM) were determined by bioelectrical impedance analysis using a body composition analyser (model TBF-300; TANITA France, Neuilly-surSeine, France). Body mass index (Weight//Height $\left.{ }^{2}\right)$ and fat-free mass index $($ FFMI $=$ FFM/Height ${ }^{2}$ ) were then calculated.

\subsection{Cell culture products}

Dulbecco's modified Eagle's medium (DMEM), nutrient mixture F-12 (Ham), nutrient mixture F-10 (Ham), horse serum were purchased from Sigma, fetal calf serum (FCS) from 
Hyclone. $\mathrm{CoCl}_{2}$ (Aldrich) was diluted in DMEM. Recombinant myostatin was purchased from R\&D Systems.

\subsection{Primary human muscle cell culture}

Quadriceps muscle biopsie of a human adult (male, age 38 years) was obtained from the "AFM-BTR Banque de tissus pour la recherche" (Hôpital de la Pitié-Salpêtrière, Paris, France). Human myoblasts were initially prepared, purified and cultured as previously described (Jean et al., 2009). Cells were plated at a density of $3 \times 10^{4}$ cells $/ \mathrm{cm}^{2}$ on Collagencoated Petri dishes (BD Biosciences), in growth medium DMEM supplemented with 20\% serum and $2 \%$ ultroser (Gibco BRL). They were maintained at $37^{\circ} \mathrm{C}$ in a water-saturated atmosphere containing 5\% $\mathrm{CO} 2$ in air. When human myoblasts reach confluency, differentiation was induced by serum depletion ( $2 \%$ FCS). Cells were kept in differentiation medium for 4 days.

\subsection{Primary mouse muscle cell culture}

Myostatin-/- mice, harboring a constitutive deletion of the third myostatin exon, have been described previously (Grobet et al., 2003) and were generously provided by L. Grobet (Faculty of Veterinary Medicine, University of Liège, Belgium). Animals were maintained on a $12 \mathrm{~h}: 12 \mathrm{~h}$ light/dark cycle and were allowed free access to food. Mice were genotyped by polymerase chain reaction analysis of tail DNA. In vitro studies were performed using male mice between 4 and 6 weeks of age. Briefly, murine myoblasts were isolated from the whole mice muscles of the paw after enzymatic digestion by pronase (Descamps et al., 2008; Levin et al., 2001). Cells were plated at a density of $2 \times 10^{4}$ cells $/ \mathrm{cm}^{2}$ on Matrigel@-coated Petri dishes (BD Biosciences, France), in 80\% Ham's F10 supplemented with 20\% horse serum (HS) (Sigma). They were maintained at $37^{\circ} \mathrm{C}$ in a water-saturated atmosphere containing $5 \%$ 
$\mathrm{CO}_{2}$ in air. After 2 days, cells were washed with Ham's F10 and placed in complete medium supplemented with $5 \mathrm{ng} / \mathrm{ml}$ basic fibroblast growth factor (bFGF). After two days, to achieve differentiation, satellite cells were switched to differentiation medium consisting of Ham's F10, 20\% HS without bFGF. Cells were kept in differentiation medium for 3 days.

\subsection{Western blot}

Muscle tissues or cells were lysed in hypotonic buffer $(20 \mathrm{mM}$ Tris $\mathrm{pH} 7.5,10 \mathrm{mM}$ $\mathrm{NaCl}$ ) and protein concentrations were determined using the BioRad DC kit (Biorad). 50 $\mu \mathrm{g}$ of total proteins diluted in 1x Laemmli buffer (100mM Tris-HCl, $\mathrm{pH} 6.8,4 \%$ SDS, $20 \%$ glycerol, 200mM DTT, bromophenol blue) were transferred to nitrocellulose membranes (Schleicher and Schull Bioscience, Dassel, Germany). Western blots were performed as previously described (Froeschle et al., 1998). The following primary antibodies were used: monoclonal anti-MHC fast (Sigma) diluted 1/1000, which recognizes all three adult fast MHC isoforms; monoclonal anti-tubulin $\alpha$ (Sigma) diluted 1/5000; polyclonal anti-myostatin (Abcam) diluted 1/500, monoclonal anti-Hif1 $\alpha$ (Novus/Interchim) diluted 1/200, monoclonal anti-actin sarcomeric (Sigma) diluted 1/1000. After washing, primary antibodies were detected with peroxidase-conjugated secondary antibodies (Amersham, Les Ulis, France) at a dilution of 1/5000 and an ECL kit.

To detect myostatin in serum, human serum samples were removed of albumin and IgG using Albumin and IgG removal kit (Amersham-Biosciences). This procedure allows an increase in the protein load of the less abundant proteins. Protein concentrations from human serum samples were determined using the BioRad DC kit (Biorad). Human serum samples (50 $\mu \mathrm{g}$ per lane) supplemented with laemmli loading buffer were subjected to SDS-polyacrylamide gel electrophoresis under reducing conditions and Western blot analysis was performed with 
the use of the rabbit polyclonal anti-myostatin (Abcam) raised against the $\mathrm{COOH}$-terminal of human myostatin.

\subsection{RNA analysis}

Total RNA was prepared using the guanidium thiocyanate procedure and analyzed by Northern blot as previously described (Chomczynski and Sacchi, 1987). For Northern blot

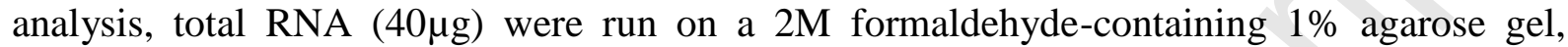
transferred and bound to nylon membranes (Hybond, Amersham) as described by supplier.

Filters were hybridized using atrogin-1/MAFbx cDNA (from S. Leibovitch, INRA Montpellier) and GAPDH cDNA (Fort et al., 1987) probes which were labeled by random priming. Radioactivity on the nylon membranes was determined on a PhosphoImager analyser (Molecular Dynamics). Expression of atrogin-1/MAFbx was normalized to GAPDH mRNA signal.

For semi-quantitative RT-PCR, $1 \mu \mathrm{g}$ of total RNA was reverse transcribed into cDNA with Reverse transcription System (Promega) following the manufacturer's instructions. One-tenth of the cDNA was used in each polymerase chain reaction using Promega GoTaq polymerase. Ethidium bromide intensity of agarose electrophoretic bands was quantified with ImageJ software in the linear amplification range determined from 20 to 35 PCR cycle amplifications. Primers for the rat myostatin (Mendler et al., 2000) and rat GAPDH (Zador et al., 1996) genes were used for amplification as described previously.

\subsection{Immunofluorescence and myotube analysis}

Human myotubes or murine myotubes were fixed in PBS containing $4 \%$ paraformaldehyde (Electron Microscopy Sciences) and treated with PBS 0.5\% triton X-100. Expression of myosin heavy chain was analysed using mouse monoclonal antibody against 
monoclonal anti-fast myosin heavy chain (MHC) diluted 1/100 (Sigma). Primary antibody diluted in PBS/BSA was incubated for $1 \mathrm{~h}$ at $37^{\circ} \mathrm{C}$, then washed in PBS, followed by a 30-min incubation with fluorescein-conjugated anti-mouse (1/5000; Amersham). DNA was stained with Hoechst $(0.1 \mu \mathrm{g} / \mathrm{ml}$; Sigma). The diameter of at least 300 myotubes was measured using PerfectImage software. The average diameter per myotube was calculated as the mean of 5 measurements taken along the length of the myotube.

\subsection{Antibodies and recombinant myostatin treatments}

To analyse the effects of antimyostatin antibodies, human myoblasts were seeded at a density of $3 \times 10^{4}$ cells $/ \mathrm{cm}^{2}$ in $35 \mathrm{~mm}$ plates in growth medium consisting of DMEM supplemented with 20\% serum and 2\% ultroser (Gibco BRL). Three days later, culture medium was changed to DMEM-2\% FCS supplemented daily with rabbit antimyostatin antibodies (directed against the $\mathrm{COOH}$-terminal region of human myostatin; diluted $1 / 50$ ) or with a preimmune serum as control. $\mathrm{CoCl}_{2}$ treatment was performed three days after the shift of medium for additional $24 \mathrm{~h}$, then the cultures were harvested for immunofluorescence analysis. Prior addition to cell medium, antibodies were dialysed against DMEM.

To analyse the effects of recombinant myostatin, murine myoblasts plated at a density of $2 \times 10^{4}$ cells $/ \mathrm{cm}^{2}$ on Matrigel-coated Petri dishes (BD Biosciences), were grown successively in growth medium Ham's F10 supplemented with 20\% horse serum (HS) during 48h, then for additional $48 \mathrm{~h}$ in growth medium supplemented with $5 \mathrm{ng} / \mathrm{ml}$ basic fibroblast growth factor. Then to achieve differentiation, myoblasts were switched to differentiation medium consisting of Ham's F10, 20\% HS without bFGF. Two days after the shift of medium, myotubes were treated for $24 \mathrm{~h}$ with either or both of $\mathrm{CoCl}_{2}(200 \mu \mathrm{M})$ or recombinant myostatin $(1 \mu \mathrm{g} / \mathrm{ml})$, and then harvested for immunofluorescence analysis. 


\subsection{Transient transfections and luciferase activity}

Primary murine myoblasts were plated at a density of $1 \times 10^{4}$ cells $/ \mathrm{cm}^{2}$ and of respectively (in 24 multiwell plates) in growth medium. After 3 days myoblasts were transfected using a dreamfect gold reagent as described by the supplier (OZBiosciences) with $1 \mu \mathrm{g}$ of total DNA composed of $100 \mathrm{ng}$ of the luciferase reporter construct (pGL3(CAGA)12-MLP-Luc) and 100 ng of RL-tk-luc (Promega, Charbonnieres, France). The total amount of DNA used for each plate was normalized with the empty expression vector pcDNA3. To evaluate luciferase activity, 24h after transfection cells were refed with differentiation medium supplemented or not with recombinant myostatin $(1 \mu \mathrm{g} / \mathrm{ml}) .48 \mathrm{~h}$ after transfection, transfected cells were harvested for luciferase assay. RL-tk-luc plasmid was included in transfections as internal control for transfection efficiency. Activities of firefly and renilla luciferases were measured sequentially using the luciferase assay kit reagent as described by the supplier (Promega, Charbonnières, France). Luciferase activity (reporter activity) was measured and corrected with respect to pRL-tk activity and protein content of the extracts.

\subsection{Statistical analysis}

The results are expressed as mean \pm SEM. Experimental conditions were compared to control conditions by Student's tests after checking the standard assumptions of parametric tests. When the standard assumptions were violated, a Mann-Whitney test was performed. When experimental designs included one factor and more than two experimental conditions, one-way ANOVA was conducted after testing standard assumptions. When a main effect was identified, Dunnet post -hoc test was used to localise the differences. A two-way ANOVA was conducted to analyse the data presented in figure 6 . The experimental design included two factors: $\mathrm{CoCl}_{2}$ treatment (four doses) and myostatin expression (+/+ and -/- myostatin 
muscles). Significant interaction between these two factors were checked (Prism 3.0, GraphPad, San Diego, CA). Statistical significance was set at $P$-values $<0.05(*)$

\section{Results}

\section{Myostatin gene expression is induced in muscles of rats chronically exposed to hypoxia}

To explore the potential relationship between hypoxia and myostatin, we used a model of long-term exposure of rats (5 weeks) to chronic hypoxia (mimicking an altitude of $4500 \mathrm{~m}$ ) associated with pair fed experimental design. As shown in Table 1, after 5 weeks the final body weight was significantly reduced in chronic hypoxic rats $(\mathrm{H})$ and in normoxic pairfed rats (Npf) in comparison with corresponding normoxic control animals (N). Similarly, Gastrocnemius (GAS) muscle weights were lower for $\mathrm{H}$ and $\mathrm{Npf}$ groups compared to $\mathrm{N}$ group (Table 1). Soleus (SOL) mass was significantly decreased in $\mathrm{H}$ animals versus $\mathrm{N}$ animals while it was only modestly and non-significantly lower in the Npf group than in the $\mathrm{N}$ group. Moreover we observed a significant decreased of total protein content in the GAS between $\mathrm{H}$ and $\mathrm{N}$ group but not in the SOL. Comparison between $\mathrm{H}$ group $v s \mathrm{Npf}$ group showed a significant effect of hypoxia on the decrease of relative GAS muscle weight and of absolute SOL muscle weight. It should be noted that except for the values of the total protein content in SOL, all the values tended to be lower in $\mathrm{H}$ rats than in Npf rats. Since in multiple models of skeletal muscle atrophy, the muscle-specific F-box protein Atrogin-1/MAFbx is upregulated (Gomes et al., 2001), we then compared by Northern blot analysis atrogin1/MAFbx mRNA expression in hypoxic $(\mathrm{H})$ versus pair-fed normoxic $(\mathrm{Npf})$ and normoxic control muscles $(\mathrm{N})$. Muscles showed an increase in atrogin-1/MAFbx mRNA expression in $\mathrm{H}$ vs $\mathrm{N}(\mathrm{P}<0.001)$ and $v s \mathrm{Npf}(\mathrm{P}<0.05)$ (Fig. 1A and $\mathrm{B})$. Note that normoxic pair-fed animals exhibited an increased atrogin-1/MAFbx expression both in the $\mathrm{SOL}(\mathrm{Npf} v s \mathrm{~N}, \mathrm{P}<0.01)$ and the GAS muscle (Npf vs $\mathrm{N}, \mathrm{P}<0.05)$. Such observation indicates that part of hypoxia-induced 
MAFbx expression is due to caloric restriction associated with hypoxia. Collectively, our results suggest that hypoxic rats show a tendency to lose more muscle mass than normoxic pair fed rats.

In this model, we then examined the expression at the protein level of the myostatin gene in Soleus (SOL) and Gastrocnemius (GAS) muscles. We performed western blotting analysis using polyclonal antimyostatin antibody. In accordance with previous data (Mendler et al., 2007), we detected a single protein band (at about $28 \mathrm{kDa}$ ) in total protein extracts of rat muscles corresponding to active myostatin. We found that SOL and GAS muscles chronically exposed to hypoxia displayed increased levels of myostatin protein as compared with normoxic pair fed SOL and GAS muscles (approximately a 1.7-fold increase in SOL and a 1.3 -fold increase in GAS) (Fig. 2A and B). Myostatin mRNA levels relative to GAPDH significantly increased upon hypoxia (Fig. 2C). Levels of GAPDH mRNA were not significantly affected by hypoxia. Thus these results indicate that in hypoxic muscles the changes in the pool of myostatin protein appear to parallel the fluctuations in myostatin mRNA level (Fig. 2C). Note that there is no variation of myostatin expression between normoxic and normoxic pair fed animals.

\section{Myostatin levels are increased in COPD patients}

To extend these findings, we investigated the effect of chronic hypoxaemia on myostatin in COPD patients. We hypothesized that an increase in myostatin might occur in patients with COPD. To test this hypothesis, we explored myostatin protein level in muscle biopsies obtained from COPD patients showing hypoxaemia. These patients were compared with sedentary control subjects of a similar age (in a attempt to diminish the influence of aging and physical activity). The main characteristics of the studied subjects are given (Table 2). As listed, no significant differences in weight, BMI were found between patients with 
COPD and sedentary age-matched healthy subjects. Similarly the mean fibre cross sectional area did not significantly differ between controls and patients with COPD (our unpublished observation). Pulmonary function testing confirmed the presence of very severe disease among the patient group. On average, COPD patients also had severe airflow limitation $\left(\mathrm{FEV}_{1}\right.$, and $\mathrm{FEV}_{1} / \mathrm{FVC}$ were significantly lower in patients compared with controls), and low values of $\mathrm{PaO}_{2}$. In addition, both peripheral muscle function as assessed by quadriceps force and endurance, and exercise tolerance, as assessed by 6-MWD, were significantly lower in patients compared with controls. Therefore these results attest muscle dysfunction in our patient group without signs of muscle atrophy. A representative western blot for myostatin is provided in Fig. 3A showing that myostatin protein level is increased in the vastus lateralis quadriceps of patients with COPD compared with control subjects. The mean myostatin protein level is 2.5 -fold higher in the COPD group than in the control group $(\mathrm{P}<0.05)$ (Fig. 3B). These results indicate that levels of myostatin are elevated in skeletal muscle of patients with COPD. Together our results suggest a potential regulation of myostatin by hypoxia.

Several experiments have shown that myostatin circulates in serum as part of a latent complex. Myostatin is detected by western blot in serum samples from mice and human (Gonzalez-Cadavid et al., 1998; Heineke et al., 2010; Schuelke et al., 2004; Zimmers et al., 2002). This prompted us to measure myostatin levels in some of our patient's serum samples. A representative Western blot for myostatin is provided and revealed a band at approximately $15 \mathrm{kD}$, consistent with the secreted form of myostatin (Hill et al., 2002; Zimmers et al., 2002). We found that myostatin protein levels tended to be increased in the serum of COPD group compared with that of the group of healthy controls (Fig. 3C and D).

\section{$\mathrm{CoCl}_{2}$ treatment induces myostatin expression and causes atrophy of myotubes}


To investigate the effects of hypoxia in vitro on myostatin expression we treated human myotubes with the cobalt chloride $\left(\mathrm{CoCl}_{2}\right)$ which mimics hypoxia by inducing HIF-1 $\alpha$ function (Bruick and McKnight, 2001; Wang et al., 1995). Briefly, in differentiating medium ( $2 \%$ FCS) confluent human myoblasts exit the cell cycle and spontaneously differentiate into multinucleated cells (myotubes) that express muscle-specific structural proteins. Human myoblasts were differentiated in low serum medium for 3 days, then myotubes were treated with $\mathrm{CoCl}_{2}(200 \mu \mathrm{M})$ for an additional $24 \mathrm{~h}$ and examined for myotube size by immunofluorescence analysis using anti-myosin heavy chain antibody (Fig. 4A). Four days after differentiation, the control myotubes were of constant size and myoblast fusion no longer occurred (Rommel et al., 2001). Myotubes exposed to $\mathrm{CoCl}_{2}$ for $24 \mathrm{~h}$ display a significant decreased size with a $24 \%$ reduction $(\mathrm{P}<0.01)$ in mean myotube diameter compared with non treated myotubes (Fig. 4B). We next wanted to investigate whether expression of myostatin was altered by $\mathrm{CoCl}_{2}$ treatment in human cells. Western blot analysis revealed that addition of $\mathrm{CoCl}_{2}$ elicited an increase in myostatin protein level in human myotubes (about 2-fold) (Fig. 4C). As expected, Western blot analysis revealed that addition of $\mathrm{CoCl}_{2}$ elicited an increase in $\mathrm{HIF} 1-\alpha$ protein after $24 \mathrm{~h}$ of treatment, attesting that $\mathrm{CoCl}_{2}$ mimics hypoxia in these cells (Fig. 4C). Furthermore, in the same conditions, levels of -the muscle structural protein $\mathrm{MHC}$ were decreased in human myotubes treated with $\mathrm{CoCl}_{2}$. These experiments clearly demonstrate that $\mathrm{CoCl}_{2}$ induces atrophy of myotubes. They also indicate an association between the level of myostatin expression and the $\mathrm{CoCl}_{2}$-induced atrophy.

\section{Myostatin is necessary to mediate the effects of $\mathrm{CoCl}_{2}$}

To confirm the role of myostatin in $\mathrm{CoCl}_{2}$-induced muscle atrophy, we employed a battery of approaches. First, we investigated whether targeted inhibition of myostatin, through addition of blocking antimyostatin antibodies, could inhibit $\mathrm{CoCl}_{2}$ mediated atrophy of human 
myotubes. We have previously validated such strategy in human tumoral muscle cells (Ricaud et al., 2005). Human muscle cells were induced to differentiate in low serum medium daily supplemented with antimyostatin antibodies $(\mathrm{Ab})$ or a preimmune serum as control $(\mathrm{Ctl})$ for 3 days, then they were treated for an additional $24 \mathrm{~h}$ with either or both of $\mathrm{CoCl}_{2}(200 \mu \mathrm{M})$ or $\mathrm{Ab}$ $(20 \mu \mathrm{g} / \mathrm{ml})$, and examined for myotube size by immunofluorescence analysis using antimyosin heavy chain antibody (Fig. 5A). We observed that culture in presence of antimyostatin antibodies significantly induced the formation of larger myotubes as compared with culture cell incubated with preimmune serum (Fig. 5B). As expected, $\mathrm{CoCl}_{2}$ treatment induced myotube atrophy in preimmune treated cells. In contrast, myotubes treated with antimyostatin antibodies were refractory to atrophic $\mathrm{CoCl}_{2}$ effect.

Second, we asked whether myostatin deletion was sufficient to impair the atrophic response of myotubes to $\mathrm{CoCl}_{2}$. To this end we established primary cultures of myoblasts from wild-type and myostatin -/- mice muscles. We differentiated myoblasts to multinucleated myotubes by mitogen removal. Two days after differentiation, differentiated myotubes are predominant and are treated with increasing concentrations of $\mathrm{CoCl}_{2}$ for one day and examined for changes in myotube diameter. It is of note that the mean diameter of myostatin -/- myotubes was significantly $12 \%$ higher than that of the wild-type (Fig. 6A and B). The decrease in wild-type myotube diameter by $\mathrm{CoCl}_{2}$ was detectable at a concentration of $25 \mu \mathrm{M}$ with a $20 \%$ decrease and reaching a maximum (30\% decrease) at $50 \mu \mathrm{M}$ (Fig. $6 \mathrm{~B})$. Conversely, the effect of $\mathrm{CoCl}_{2}$ was significantly blunted in myostatin -/- cells, the maximal effect $(10 \%)$ being detectable at $50 \mu \mathrm{M}$. Thus myotubes lacking myostatin have an impaired atrophic response to $\mathrm{CoCl}_{2}$. We next examined the effect of recombinant myostatin on the $\mathrm{CoCl}_{2}$ mediated atrophy in this system model. We first tested the activity of recombinant myostatin following transient transfection into murine cells with the use of the pGL3(CAGA)12 luciferase reporter assay which reflects myostatin activity (Thies et al., 2001; 
Zimmers et al., 2002). We found that CAGA reporter was activated by myostatin (Fig. 7A). Next we asked whether addition of recombinant myostatin was sufficient to restore the atrophic response of myostatin deficient myotubes to $\mathrm{CoCl}_{2}$. Two days after differentiation, wild type and myostatin -/- cells were treated for $24 \mathrm{~h}$ with either or both of $\mathrm{CoCl}_{2}(200 \mu \mathrm{M})$ or recombinant myostatin $(1 \mu \mathrm{g} / \mathrm{ml})$. We then examined myotube size by immunofluorescence analysis using anti-myosin heavy chain antibody (Fig. 7B and 7C). In wild-type cells, myostatin did not modify the atrophic response of myotubes to $\mathrm{CoCl}_{2}$. Conversely, in myostatin -/- cells, myostatin was sufficient to restore the atrophic response to $\mathrm{CoCl}_{2}$. Note that at this low dose and during this short period of treatment myostatin by itself did not significantly induce myotube atrophy.

\section{Discussion}

In this study, we report upregulation of myostatin expression in muscles of rats chronically exposed to severe hypoxia as well as in muscles of patients with chronically hypoxemic COPD. Furthermore, our data show that $\mathrm{CoCl}_{2}$, an hypoxia-mimicking agent, increases the expression of myostatin and causes atrophy of myotubes in human and mouse cell cultures. Finally, we provided compelling evidence that the $\mathrm{CoCl}_{2}$ atrophic effect is linked to myostatin expression. Indeed, this atrophic effect is not observed in muscle cells where myostatin is inactivated either through genetic deletion or by using blocking antimyostatin antibodies. Inversely, the presence of myostatin restores the $\mathrm{CoCl} 2$ induced atrophy in myostatin deficient myotubes.

In an attempt to identify proper effects of hypoxia on myostatin in muscle we took advantage of a model of rats chronically exposed to severe hypoxia with a pair fed experimental design which excludes the anorexic impact of hypoxia on skeletal muscle mass. 
Accordingly, our results show a trend towards a higher diminution of skeletal muscle mass in hypoxic rats than in normoxic pair fed rats. In addition, at the molecular level this effect is associated with a significant induction of the MAFbx, suggesting an activation of proteasomal degradation which could contribute to a reduction in skeletal muscle mass (Gomes et al., 2001). Thus these data are in agreement with previous studies suggesting a direct effect of hypoxia per se in the induction of skeletal muscle atrophy independent of energy intake status (Bigard et al., 1996; Favier et al., 2010; Pison et al., 1998). Interestingly, comparison between $\mathrm{H}$ vs Npf groups showed a significant decrease in muscle weight in the SOL but not the GAS muscle (Table 1). This muscle specific effect of hypoxia may be explained by the difference in the metabolism of slow and fast muscles. Indeed, compared to GAS muscle SOL muscle exhibits a more oxidative metabolism and is more dependent on the availability of $\mathrm{O}_{2}$. Thus, SOL muscle could show a greater sensitivity to hypoxia. However the mechanisms producing the differences in response remain to be elucidated.

An interesting feature of the present study was the induction of myostatin by hypoxia. Our data clearly show that myostatin expression is induced in hypoxic muscles compared to normoxic pair-fed muscles whereas the decreased food intake failed to increase myostatin expression. However, it should be noted that myostatin expression is induced in a model of muscle atrophy induced by a more severe food deprivation (Allen et al., 2010). This discrepancy may be related to differences in both severity of the food deprivation stress and length of exposure. Therefore, our observation indicates that hypoxia exerts its inducer effect on myostatin expression independently of nutritional status.

Skeletal muscle dysfunction is a prominent feature of COPD, and hypoxia, among other factors, is a proposed contributor to this process while the underlying molecular mechanisms remain to be identified. There is evidence that COPD patients are prone to develop muscle atrophy which is now recognized as a predictor of mortality in this disease 
(Doucet et al., 2007; Marquis et al., 2002). Several recent reports suggested that upregulation of myostatin is involved in the development of muscle atrophy associated with COPD (Plant et al., 2009; Testelmans et al., 2010). In the present study, our results showed an increased skeletal muscle myostatin expression in hypoxemic COPD patients $\left(\mathrm{PaO}_{2}=64 \pm 2 \mathrm{~mm} \mathrm{Hg}\right)$ compared with that in healthy controls. Consistent with these data, we also found that myostatin protein level tend to increase in the serum of COPD group compared with that of the group of healthy controls. However, it is of note that we obtained this result with a limited number of subjects ( $\mathrm{n}=3-4$ /group). Thus to definitely conclude a greater number of subjects should be analysed.

It is thus tempting to suggest that the increase in myostatin is causally related to muscle atrophy in this pathological context. However, no characteristics of global muscle atrophy, such as fat-free mass index, BMI and mean fibre cross sectional area were found in our patients compared to age-matched sedentary controls, although COPD patients showed reduced quadriceps force. It remains possible that an increase in myostatin expression could precede the induction of muscle atrophy. Collectively our data tend to implicate the hypoxic regulation of myostatin in patients with COPD and suggest that myostatin induction could be related to the presence of COPD itself rather to muscle atrophy. However, it should be noted that, in addition to hypoxaemia, several factors including inflammation, oxidative stress have been implicated in muscle limb dysfunction in COPD (Couillard and Prefaut, 2005). It is thus conceivable that inflammation and oxidative stress may also contribute alone or in concert with hypoxaemia to the higher myostatin expression levels. Further studies should be designed to address this point.

In agreement with our in vivo observations, our results showed that addition of the hypoxia mimic cobalt chloride $\mathrm{CoCl}_{2}$ elicits a significant increase in myostatin expression and causes atrophy of human myotubes. We further demonstrated that $\mathrm{CoCl}_{2}$ requires the presence 
of myostatin to elicit its action on muscle cells since: i) the atrophic $\mathrm{CoCl}_{2}$ effect is not observed both in human myotubes treated with antimyostatin antibodies and in murine myostatin deficient myotubes while ii) myostatin deficient myotubes treated with recombinant myostatin displayed an atrophic response to $\mathrm{CoCl}_{2}$. Altogether, these data strongly argue for a critical role for myostatin in mediating hypoxia effects in skeletal muscle cells. Can we link the hypoxia-induced atrophy to the up-regulation of myostatin expression? Several studies have established the catabolic effect of myostatin on skeletal muscle. In vitro, myostatin not only inhibits myoblast proliferation and differentiation but also induces atrophy of resulting myotubes (McCroskery et al., 2003; Rios et al., 2002; Taylor et al., 2001; Thomas et al., 2000). In vivo, systemic administration of myostatin to adult mice or overexpression of myostatin in skeletal muscle also results in muscle atrophy (Durieux et al., 2007; ReiszPorszasz et al., 2003; Zimmers et al., 2002). Inversely, myostatin gene deletion prevents glucocorticoid-induced muscle atrophy (Gilson et al., 2007) and the effect of glutamine on prevention of glucocorticoid-induced skeletal muscle atrophy is associated with myostatin suppression (Salehian et al., 2006). Supporting its atrophic action, it has been demonstrated that myostatin decreases phosphorylation and nuclear export of the FoxO transcription factors by Akt (McFarlane et al., 2006), impairs protein synthesis in vitro (Taylor et al., 2001) and negatively regulates Akt/mTOR signalling pathway, which controls protein synthesis (Amirouche et al., 2009). Recently, Favier et al. demonstrated that Akt/mTOR pathway is down-regulated in rat skeletal muscle in response to chronic hypoxia indicating that hypoxia negatively regulates protein synthesis in skeletal muscle (Favier et al., 2010). Therefore, the parallel actions of myostatin and hypoxia on protein synthesis suggest that induction of myostatin by hypoxia could represent a potential mechanism for hypoxia-induced atrophy.

The present data suggest the contribution of myostatin, a member of TGF $\beta$ family, in the skeletal muscle response to hypoxic stimuli. Interestingly, earlier findings on other tissues 
have shown that various effects of hypoxia appear to be mediated by TGF $\beta$ signalling. TGF $\beta$ expression is up-regulated in lung of hypoxia-adapted animals (Bartram and Speer, 2004). In human peritoneal fibroblasts, hypoxia increases TGF $\beta 1$ and TGF- $\beta$ type I and II receptors mRNA levels (Saed et al., 2002). Chronic hypoxia-induced pulmonary hypertension and vascular remodeling are attenuated in absence of TGF $\beta$ signalling (Chen et al., 2006). Similarly, TGF $\beta$ signalling is required for the inhibition of adipocyte differentiation by hypoxia. These previous results, together with our findings, support the hypothesis that TGF$\beta$ signalling could mediate the response to hypoxic stress in several tissues. To our knowledge, a link between myostatin and hypoxia would represent a novel facet of the hypoxic response in muscle. However, additional in vivo experiments are further needed to detail the myostatin action in the skeletal muscle response to hypoxia.

In conclusion, the data presented here demonstrate a link between hypoxia and myostatin and provide insights into how hypoxia contributes to muscle dysfunction. We believe that they could have important biologic and therapeutic implications, since they offer important clues to understand the mechanisms of hypoxia action in muscle and may open possibilities for the development of new treatments for skeletal muscle disease.

\section{ACKNOWLEDGMENTS:}

This study was supported by funds from the Institut National de la Recherche Agronomique (INRA), the "fédération ANTADIR (Association Nationale pour le Traitement à Domicile, l'Innovation et la Recherche)", and the Centre Hospitalier Universitaire de Montpellier. The authors would like to thank: Drs Guillaume Py, Christelle Koechlin and Arnaud Chatonnet for their useful discussions and Adrien Gibault for technical assistance. We thank Miss B. Bonafos, and Miss V. Rana for taking care of animals used in the present study 
and their genotyping, respectively. J.R. is the recipient of a doctoral fellowship cofinanced by INRA and Région Languedoc-Roussillon. 


\section{REFERENCES}

(2002). ATS statement: guidelines for the six-minute walk test. Am J Respir Crit Care Med 166, 111-7.

Agusti, A. G., Noguera, A., Sauleda, J., Sala, E., Pons, J. and Busquets, X. (2003). Systemic effects of chronic obstructive pulmonary disease. Eur Respir J 21, 347-60.

Allen, D. L., Cleary, A. S., Lindsay, S. F., Loh, A. and Reed, J. M. (2010). Myostatin Expression is Increased by Food Deprivation in a Muscle-Specific Manner and Contributes to Muscle Atrophy during Prolonged Food Deprivation in Mice. J Appl Physiol.

Amirouche, A., Durieux, A. C., Banzet, S., Koulmann, N., Bonnefoy, R., Mouret, C., Bigard, X., Peinnequin, A. and Freyssenet, D. (2009). Down-regulation of Akt/mammalian target of rapamycin signaling pathway in response to myostatin overexpression in skeletal muscle. Endocrinology 150, 286-94.

Bartram, U. and Speer, C. P. (2004). The role of transforming growth factor beta in lung development and disease. Chest 125, 754-65.

Bergstrom, J. (1975). Percutaneous needle biopsy of skeletal muscle in physiological and clinical research. Scand J Clin Lab Invest 35, 609-16.

Bigard, A. X., Douce, P., Merino, D., Lienhard, F. and Guezennec, C. Y. (1996). Changes in dietary protein intake fail to prevent decrease in muscle growth induced by severe hypoxia in rats. $J$ Appl Physiol 80, 208-15.

Bruick, R. K. and McKnight, S. L. (2001). A conserved family of prolyl-4hydroxylases that modify HIF. Science 294, 1337-40.

Chen, Y. F., Feng, J. A., Li, P., Xing, D., Zhang, Y., Serra, R., Ambalavanan, N., Majid-Hassan, E. and Oparil, S. (2006). Dominant negative mutation of the TGF-beta receptor blocks hypoxia-induced pulmonary vascular remodeling. J Appl Physiol 100, 564-71.

Chomczynski, P. and Sacchi, N. (1987). Single-step method of RNA isolation by acid guanidinium thiocyanate-phenol-chloroform extraction. Anal Biochem 162, 156-9.

Clop, A., Marcq, F., Takeda, H., Pirottin, D., Tordoir, X., Bibe, B., Bouix, J., Caiment, F., Elsen, J. M., Eychenne, F. et al. (2006). A mutation creating a potential illegitimate microRNA target site in the myostatin gene affects muscularity in sheep. Nat Genet 38, 813-8.

Couillard, A. and Prefaut, C. (2005). From muscle disuse to myopathy in COPD: potential contribution of oxidative stress. Eur Respir J 26, 703-19.

Delample, D., Durand, F., Severac, A., Belghith, M., Mas, E., Michel, F., Cristol, J. P., Hayot, M. and Prefaut, C. (2008). Implication of xanthine oxidase in muscle oxidative stress in COPD patients. Free Radic Res 42, 807-14.

Descamps, S., Arzouk, H., Bacou, F., Bernardi, H., Fedon, Y., Gay, S., Reyne, Y., Rossano, B. and Levin, J. (2008). Inhibition of myoblast differentiation by Sfrp1 and Sfrp2. Cell Tissue Res 332, 299-306.

Doucet, M., Russell, A. P., Leger, B., Debigare, R., Joanisse, D. R., Caron, M. A., LeBlanc, P. and Maltais, F. (2007). Muscle atrophy and hypertrophy signaling in patients with chronic obstructive pulmonary disease. Am J Respir Crit Care Med 176, 261-9.

Durieux, A. C., Amirouche, A., Banzet, S., Koulmann, N., Bonnefoy, R., Pasdeloup, M., Mouret, C., Bigard, X., Peinnequin, A. and Freyssenet, D. (2007). Ectopic expression of myostatin induces atrophy of adult skeletal muscle by decreasing muscle gene expression. Endocrinology 148, 3140-7.

Favier, F. B., Costes, F., Defour, A., Bonnefoy, R., Lefai, E., Bauge, S., Peinnequin, A., Benoit, H. and Freyssenet, D. (2010). Downregulation of Akt/mammalian target of rapamycin pathway in skeletal muscle is associated with increased REDD1 
expression in response to chronic hypoxia. Am J Physiol Regul Integr Comp Physiol 298, R1659-66.

Fort, P., Rech, J., Vie, A., Piechaczyk, M., Bonnieu, A., Jeanteur, P. and Blanchard, J. M. (1987). Regulation of c-fos gene expression in hamster fibroblasts: initiation and elongation of transcription and mRNA degradation. Nucleic Acids Res 15, 5657 67.

Froeschle, A., Alric, S., Kitzmann, M., Carnac, G., Aurade, F., Rochette-Egly, C. and Bonnieu, A. (1998). Retinoic acid receptors and muscle b-HLH proteins: partners in retinoid-induced myogenesis. Oncogene 16, 3369-78.

Gilson, H., Schakman, O., Combaret, L., Lause, P., Grobet, L., Attaix, D., Ketelslegers, J. M. and Thissen, J. P. (2007). Myostatin gene deletion prevents glucocorticoid-induced muscle atrophy. Endocrinology 148, 452-60.

Gomes, M. D., Lecker, S. H., Jagoe, R. T., Navon, A. and Goldberg, A. L. (2001). Atrogin-1, a muscle-specific F-box protein highly expressed during muscle atrophy. Proc Natl Acad Sci U S A 98, 14440-5.

Gonzalez-Cadavid, N. F., Taylor, W. E., Yarasheski, K., Sinha-Hikim, I., Ma, K., Ezzat, S., Shen, R., Lalani, R., Asa, S., Mamita, M. et al. (1998). Organization of the human myostatin gene and expression in healthy men and HIV-infected men with muscle wasting. Proc Natl Acad Sci U S A 95, 14938-43.

Goret, L., Reboul, C., Tanguy, S., Dauzat, M. and Obert, P. (2005). Training does not affect the alteration in pulmonary artery vasoreactivity in pulmonary hypertensive rats. Eur J Pharmacol 527, 121-8.

Gosker, H. R., van Mameren, H., van Dijk, P. J., Engelen, M. P., van der Vusse, G. J., Wouters, E. F. and Schols, A. M. (2002). Skeletal muscle fibre-type shifting and metabolic profile in patients with chronic obstructive pulmonary disease. Eur Respir $J$ 19, 617-25.

Grobet, L., Martin, L. J., Poncelet, D., Pirottin, D., Brouwers, B., Riquet, J., Schoeberlein, A., Dunner, S., Menissier, F., Massabanda, J. et al. (1997). A deletion in the bovine myostatin gene causes the double-muscled phenotype in cattle. Nat Genet 17, 71-4.

Grobet, L., Pirottin, D., Farnir, F., Poncelet, D., Royo, L. J., Brouwers, B., Christians, E., Desmecht, D., Coignoul, F., Kahn, R. et al. (2003). Modulating skeletal muscle mass by postnatal, muscle-specific inactivation of the myostatin gene. Genesis 35, 227-38.

Hayot, M., Michaud, A., Koechlin, C., Caron, M. A., Leblanc, P., Prefaut, C. and Maltais, F. (2005). Skeletal muscle microbiopsy: a validation study of a minimally invasive technique. Eur Respir J 25, 431-40.

Heineke, J., Auger-Messier, M., Xu, J., Sargent, M., York, A., Welle, S. and Molkentin, J. D. (2010). Genetic deletion of myostatin from the heart prevents skeletal muscle atrophy in heart failure. Circulation 121, 419-25.

Hill, J. J., Davies, M. V., Pearson, A. A., Wang, J. H., Hewick, R. M., Wolfman, N. M. and Qiu, Y. (2002). The myostatin propeptide and the follistatin-related gene are inhibitory binding proteins of myostatin in normal serum. J Biol Chem 277, 40735-41.

Hoppeler, H., Kleinert, E., Schlegel, C., Claassen, H., Howald, H., Kayar, S. R. and Cerretelli, P. (1990). Morphological adaptations of human skeletal muscle to chronic hypoxia. Int J Sports Med 11 Suppl 1, S3-9.

Howald, H. and Hoppeler, H. (2003). Performing at extreme altitude: muscle cellular and subcellular adaptations. Eur J Appl Physiol 90, 360-4.

Jean, E., Laoudj-Chenivesse, D., Notarnicola, C., Rouger, K., Serratrice, N., Bonnieu, A., Gay, S., Bacou, F., Duret, C. and Carnac, G. (2009). Aldehyde dehydrogenase activity promotes survival of human muscle precursor cells. J Cell Mol Med. 
Kambadur, R., Sharma, M., Smith, T. P. and Bass, J. J. (1997). Mutations in myostatin (GDF8) in double-muscled Belgian Blue and Piedmontese cattle. Genome Res 7, 910-6.

Levin, J. M., El Andalousi, R. A., Dainat, J., Reyne, Y. and Bacou, F. (2001). SFRP2 expression in rabbit myogenic progenitor cells and in adult skeletal muscles. $J$ Muscle Res Cell Motil 22, 361-9.

Liu, W., Thomas, S. G., Asa, S. L., Gonzalez-Cadavid, N., Bhasin, S. and Ezzat, S. (2003). Myostatin is a skeletal muscle target of growth hormone anabolic action. J Clin Endocrinol Metab 88, 5490-6.

MacDougall, J. D., Green, H. J., Sutton, J. R., Coates, G., Cymerman, A., Young, P. and Houston, C. S. (1991). Operation Everest II: structural adaptations in skeletal muscle in response to extreme simulated altitude. Acta Physiol Scand 142, 421-7.

Marquis, K., Debigare, R., Lacasse, Y., LeBlanc, P., Jobin, J., Carrier, G. and Maltais, F. (2002). Midthigh muscle cross-sectional area is a better predictor of mortality than body mass index in patients with chronic obstructive pulmonary disease. Am J Respir Crit Care Med 166, 809-13.

McCroskery, S., Thomas, M., Maxwell, L., Sharma, M. and Kambadur, R. (2003). Myostatin negatively regulates satellite cell activation and self-renewal. J Cell Biol 162, 1135-47.

McFarlane, C., Plummer, E., Thomas, M., Hennebry, A., Ashby, M., Ling, N., Smith, H., Sharma, M. and Kambadur, R. (2006). Myostatin induces cachexia by activating the ubiquitin proteolytic system through an NF-kappaB-independent, FoxO1dependent mechanism. J Cell Physiol 209, 501-14.

McPherron, A. C., Lawler, A. M. and Lee, S. J. (1997). Regulation of skeletal muscle mass in mice by a new TGF-beta superfamily member. Nature 387, 83-90.

Mendler, L., Baka, Z., Kovacs-Simon, A. and Dux, L. (2007). Androgens negatively regulate myostatin expression in an androgen-dependent skeletal muscle. Biochem Biophys Res Commun 361, 237-42.

Mendler, L., Zador, E., Ver Heyen, M., Dux, L. and Wuytack, F. (2000). Myostatin levels in regenerating rat muscles and in myogenic cell cultures. J Muscle Res Cell Motil 21, 551-63.

Mosher, D. S., Quignon, P., Bustamante, C. D., Sutter, N. B., Mellersh, C. S., Parker, H. G. and Ostrander, E. A. (2007). A mutation in the myostatin gene increases muscle mass and enhances racing performance in heterozygote dogs. PLoS Genet $\mathbf{3}$, e79.

Moss, F. P. and Leblond, C. P. (1971). Satellite cells as the source of nuclei in muscles of growing rats. Anat Rec 170, 421-35.

Nici, L., Donner, C., Wouters, E., Zuwallack, R., Ambrosino, N., Bourbeau, J., Carone, M., Celli, B., Engelen, M., Fahy, B. et al. (2006). American Thoracic Society/European Respiratory Society statement on pulmonary rehabilitation. Am J Respir Crit Care Med 173, 1390-413.

Pison, C. M., Chauvin, C., Perrault, H., Schwebel, C., Lafond, J. L., Boujet, C. and Leverve, X. M. (1998). In vivo hypoxic exposure impairs metabolic adaptations to a 48 hour fast in rats. Eur Respir J 12, 658-65.

Plant, P. J., Brooks, D., Faughnan, M., Bayley, T., Bain, J., Singer, L., Correa, J., Pearce, D., Binnie, M. and Batt, J. (2009). Cellular Markers of Muscle Atrophy in Chronic Obstructive Pulmonary Disease (COPD). Am J Respir Cell Mol Biol.

Reardon, K. A., Davis, J., Kapsa, R. M., Choong, P. and Byrne, E. (2001). Myostatin, insulin-like growth factor-1, and leukemia inhibitory factor mRNAs are upregulated in chronic human disuse muscle atrophy. Muscle Nerve 24, 893-9. 
Reisz-Porszasz, S., Bhasin, S., Artaza, J. N., Shen, R., Sinha-Hikim, I., Hogue, A., Fielder, T. J. and Gonzalez-Cadavid, N. F. (2003). Lower skeletal muscle mass in male transgenic mice with muscle-specific overexpression of myostatin. Am J Physiol Endocrinol Metab 285, E876-88.

Ricaud, S., Vernus, B. and Bonnieu, A. (2005). Response of human rhabdomyosarcoma cell lines to retinoic acid: relationship with induction of differentiation and retinoic acid sensitivity. Exp Cell Res 311, 192-204.

Rios, R., Carneiro, I., Arce, V. M. and Devesa, J. (2002). Myostatin is an inhibitor of myogenic differentiation. Am J Physiol Cell Physiol 282, C993-9.

Rommel, C., Bodine, S. C., Clarke, B. A., Rossman, R., Nunez, L., Stitt, T. N., Yancopoulos, G. D. and Glass, D. J. (2001). Mediation of IGF-1-induced skeletal myotube hypertrophy by PI(3)K/Akt/mTOR and PI(3)K/Akt/GSK3 pathways. Nat Cell Biol 3, 100913.

Saed, G. M., Collins, K. L. and Diamond, M. P. (2002). Transforming growth factors beta 1 , beta 2 and beta 3 and their receptors are differentially expressed in human peritoneal fibroblasts in response to hypoxia. Am J Reprod Immunol 48, 387-93.

Salehian, B., Mahabadi, V., Bilas, J., Taylor, W. E. and Ma, K. (2006). The effect of glutamine on prevention of glucocorticoid-induced skeletal muscle atrophy is associated with myostatin suppression. Metabolism 55, 1239-47.

Schuelke, M., Wagner, K. R., Stolz, L. E., Hubner, C., Riebel, T., Komen, W., Braun, T., Tobin, J. F. and Lee, S. J. (2004). Myostatin mutation associated with gross muscle hypertrophy in a child. $N$ Engl $J$ Med 350, 2682-8.

Sillau, A. H. and Banchero, N. (1977). Effects of hypoxia on capillary density and fiber composition in rat skeletal muscle. Pflugers Arch 370, 227-32.

Taylor, W. E., Bhasin, S., Artaza, J., Byhower, F., Azam, M., Willard, D. H., Jr., Kull, F. C., Jr. and Gonzalez-Cadavid, N. (2001). Myostatin inhibits cell proliferation and protein synthesis in C2C12 muscle cells. Am J Physiol Endocrinol Metab 280, E221-8.

Testelmans, D., Crul, T., Maes, K., Agten, A., Crombach, M., Decramer, M. and Gayan-Ramirez, G. (2010). Atrophy and hypertrophy signalling in the diaphragm of patients with COPD. Eur Respir J 35, 549-56.

Thies, R. S., Chen, T., Davies, M. V., Tomkinson, K. N., Pearson, A. A., Shakey, Q. A. and Wolfman, N. M. (2001). GDF-8 propeptide binds to GDF-8 and antagonizes biological activity by inhibiting GDF-8 receptor binding. Growth Factors 18, 251-9.

Thomas, M., Langley, B., Berry, C., Sharma, M., Kirk, S., Bass, J. and Kambadur, R. (2000). Myostatin, a negative regulator of muscle growth, functions by inhibiting myoblast proliferation. J Biol Chem 275, 40235-43.

Voorrips, L. E., Ravelli, A. C., Dongelmans, P. C., Deurenberg, P. and Van Staveren, W. A. (1991). A physical activity questionnaire for the elderly. Med Sci Sports Exerc 23, 974-9.

Wang, G. L., Jiang, B. H., Rue, E. A. and Semenza, G. L. (1995). Hypoxiainducible factor 1 is a basic-helix-loop-helix-PAS heterodimer regulated by cellular $\mathrm{O} 2$ tension. Proc Natl Acad Sci U S A 92, 5510-4.

Whittemore, L. A., Song, K., Li, X., Aghajanian, J., Davies, M., Girgenrath, S., Hill, J. J., Jalenak, M., Kelley, P., Knight, A. et al. (2003). Inhibition of myostatin in adult mice increases skeletal muscle mass and strength. Biochem Biophys Res Commun 300, 96571.

Wouters, E. F. (2004). Management of severe COPD. Lancet 364, 883-95.

Wouters, E. F. (2005). Local and systemic inflammation in chronic obstructive pulmonary disease. Proc Am Thorac Soc 2, 26-33. 
Yarasheski, K. E., Bhasin, S., Sinha-Hikim, I., Pak-Loduca, J. and GonzalezCadavid, N. F. (2002). Serum myostatin-immunoreactive protein is increased in 60-92 year old women and men with muscle wasting. $J$ Nutr Health Aging 6, 343-8.

Zachwieja, J. J., Smith, S. R., Sinha-Hikim, I., Gonzalez-Cadavid, N. and Bhasin, S. (1999). Plasma myostatin-immunoreactive protein is increased after prolonged bed rest with low-dose T3 administration. J Gravit Physiol 6, 11-5.

Zador, E., Mendler, L., Ver Heyen, M., Dux, L. and Wuytack, F. (1996). Changes in mRNA levels of the sarcoplasmic/endoplasmic-reticulum $\mathrm{Ca}(2+)$-ATPase isoforms in the rat soleus muscle regenerating from notexin-induced necrosis. Biochem J 320 ( Pt 1), 107-13.

Zimmers, T. A., Davies, M. V., Koniaris, L. G., Haynes, P., Esquela, A. F., Tomkinson, K. N., McPherron, A. C., Wolfman, N. M. and Lee, S. J. (2002). Induction of cachexia in mice by systemically administered myostatin. Science 296, 1486-8. 


\section{TABLE LEGEND}

Table 1 : Body weights and muscle weights in normoxic $(\mathrm{N})$, normoxic pair fed $(\mathrm{Npf})$ and hypoxic (H) rats

SOL, soleus muscle; GAS, gastrocnemius muscle. Values are means \pm SEM. Significant difference $* \mathrm{P}<0.05 ; * * \mathrm{P}<0.01$ compared to $\mathrm{N}$ group, and $\ddagger \mathrm{P}<0.05$ compared to $\mathrm{Npf}$ group is given ( $\mathrm{n}=10$ per group)

\section{Table 2 : Subject characteristics}

Definitions and abbreviations: $\mathrm{BMI}=$ Body mass index; FFM $=$ fat-free mass; $F$ FMI $=$ fatfree mass index; FEV1 $=$ forced expiratory volume in one second; $\%$ pred $=\%$ predicted, $\mathrm{FVC}=$ forced vital capacity $\mathrm{MVC}=$ maximal voluntary contraction, 6-MWD = 6-minute walk distance.

Data are presented as mean \pm SEM. $* \mathrm{P}<0.05 ; * * * \mathrm{P}<0.001$

\section{FIGURE LEGENDS}

Fig. 1. Atrogin-1/MAFbx expression is induced in muscles of hypoxic rats

A) Hypoxia increases Atrogin-1/MAFbx mRNA level. After the experimental period, rats were killed and muscle RNA (Soleus, SOL and Gastrocnemius, GAS) were extracted from normoxic $(\mathrm{N})$, normoxic pair fed $(\mathrm{Npf})$ and hypoxic $(\mathrm{H})$ groups, $20 \mu \mathrm{g}$ of total RNA were subjected to Northern blot analysis using an Atrogin-1/MAFbx probe. A representative Northern blot is presented here. Homogeneity in RNA loading was controlled by the hybridisation of GAPDH to the same filter.

B) Quantification of Atrogin-1/MAFbx mRNA expression in muscles from normoxic $(\mathrm{N})$, normoxic pair fed $(\mathrm{Npf})$ and hypoxic $(\mathrm{H})$ rats. Atrogin-1/MAFbx mRNA levels were expressed relative to GAPDH mRNA levels. Data are presented in arbitrary units (A.U.) and 
the values are means \pm SEM, above each column the significance of the sample versus the $\mathrm{N}$ control group $(* \mathrm{P}<0.05, * * \mathrm{P}<0.01$ and $* * * \mathrm{P}<0.001)$ and versus the Npf group $(+\mathrm{P}<0.05)$ is given ( $\mathrm{n}=10$ per group).

Fig. 2. Myostatin expression is induced in soleus and gastronemius muscles of rats chronically exposed to hypoxia

A) Hypoxia increases the amount of myostatin protein in muscles. Protein extracts of

Soleus and Gastrocnemius muscles from normoxia $(\mathrm{N})$, normoxia pair-fed $(\mathrm{Npf})$ or hypoxia exposed rats $(\mathrm{H})$ were resolved on a $10 \%$ SDS-PAGE and endogenous myostatin and $\alpha$ tubulin (as a loading control) were detected by western blot analysis using specific antibodies. A representative Western blot is presented here.

B) Quantification of myostatin protein levels expressed relative to $\alpha$-tubulin levels in muscles at normoxia, normoxia pair-fed or hypoxia. Data are presented in arbitrary units (A.U.) and the values are means \pm SEM, above each column the significance of the sample versus the $\mathrm{N}$ control group $(* * \mathrm{P}<0.01)$ and versus the Npf group ( $\mathrm{P}<0.05$ and $+\$ \mathrm{P}<0.01)$ is given; ( $\mathrm{n}=10$ per group).

C) Hypoxia increases myostatin mRNA level. Transcriptional expression of myostatin was measured by sqRT-PCR on total RNA extracted from Soleus and Gastrocnemius muscles from normoxia $(\mathrm{N})$, normoxia pair-fed $(\mathrm{Npf})$ or hypoxia-exposed rats $(\mathrm{H})$. Typical RT-PCR amplification is shown. Myostatin mRNA levels are normalized to those of GAPDH, above each column the significance of the sample versus the $\mathrm{N}$ control group $(* \mathrm{P}<0.05$ and $* *$ $\mathrm{P}<0.01)$ and versus the Npf group $(\$ \mathrm{P}<0.05)$ is given; ( $\mathrm{n}=10$ per group).

\section{Fig. 3. Increased levels of myostatin in patients with COPD}

A) Myostatin protein content in muscle biopsies of COPD patients. Protein extracts were 
prepared from the quadriceps muscle biopsies of 5 control subjects and 10 patients with chronic obstructive pulmonary disease (COPD). The levels of myostatin and actin sarcomeric (as loading control) were analysis by immunoblotting with the appropriate antibodies. A representative Western blot is presented here.

B) Quantification of skeletal muscle myostatin protein levels. Results were quantified by gel scan and Image $\mathbf{J}$ and expressed relative to actin sarcomeric levels. The values are means \pm SEM, $* \mathrm{P}<0.05$ between COPD and healthy patients.

C) Myostatin expression in serum of controls and patients of COPD. Serum samples from control and COPD subjects were subjected to SDS-polyacrylamide gel electrophoresis under reducing conditions. Western blot analysis was performed with the use of a rabbit polyclonal antibody raised against human myostatin $\mathrm{COOH}$-terminal region which recognizes the secreted form of myostatin (molecular mass of about $15 \mathrm{kD}$ ).

D) Quantification of serum myostatin protein level in control and COPD patients. The myostatin level tended to be increased in the serum of patients with COPD ( $n=3-4$ per group).

\section{Fig. 4. $\mathrm{CoCl}_{2}$ treatment results in myotube atrophy and increased myostatin gene} expression in human myotubes

A) $\mathrm{CoCl}_{2}$ induces atrophy of human myotubes. Human myoblasts cultured 3 days in proliferating medium were prompted to differentiate for 4 days in differentiating medium. 3day old human myotubes were treated with $\mathrm{CoCl}_{2}(200 \mu \mathrm{M})$ for $24 \mathrm{~h}$ and immunostained with anti-Myosin Heavy Chain (MHC). Nuclei were revealed by Hoescht staining. Myotube diameter was measured at day 4 of differentiation.

B) Quantification of myotube diameter in the presence or absence of $\mathrm{CoCl}_{2}$. $* *$ indicates significant at $\mathrm{P}<0.01$. The bars represent the mean \pm SEM of two independent experiments (at least 300 myotubes). Scale bar, $20 \mu \mathrm{m}$. 
C) Stimulation of myostatin expression by $\mathrm{CoCl}_{2}$ in human myotubes. Western blot analysis was carried out for myostatin, Hif1 $\alpha$, myosin-heavy chain (MHC) and $\alpha$ tubulin as a loading control on protein extracts from human myotubes collected after $24 \mathrm{~h}$ of $\mathrm{CoCl}_{2}$ treatment.

\section{Fig. 5. Inhibition of myostatin blocks $\mathrm{CoCl}_{2}$-mediated atrophy in human muscle cells}

A) Antimyostatin antibodies inhibit the atrophic effect of $\mathrm{CoCl}_{2}$ on human myotubes.

Antimyostatin antibodies $(+\mathrm{Ab})$ or preimmune serum as control $(\mathrm{Ctl})$ were daily added to cells when they were shifted in differentiation conditions. Myotubes were then treated at day 3 after fusion with either or both of $\mathrm{CoCl}_{2}(200 \mu \mathrm{M})$ or $\mathrm{Ab}(20 \mu \mathrm{g} / \mathrm{ml})$, and analysed at day 4 of differentiation. $\mathrm{CoCl}_{2}$ caused atrophy; $\mathrm{Ab}$ blocked $\mathrm{CoCl}_{2}$-induced atrophy.

B) Quantification of human myotubes diameter in presence or absence of antimyostatin antibodies. Histograms are means for at least 3 assays. *, $\mathrm{P}<0.05$ myotubes treated with antimyostatin antibodies $(+\mathrm{Ab})$ versus untreated control myotubes $(\mathrm{Ctl}) ; \quad+, \mathrm{P}<0.05 \mathrm{CoCl}_{2}$

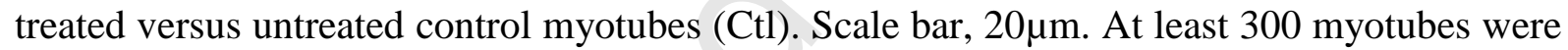
analysed.

\section{Fig. 6. Myostatin deficient myotubes are resistant to $\mathrm{CoCl}_{2}$-mediated atrophy}

Primary muscle cells from wild-type and myostatin -/- mice were allowed to differentiate for 2 days and then incubated for a further 1 day with increasing concentrations of $\mathrm{CoCl}_{2}$.

A) Effect of $\mathrm{CoCl}_{2}$ on myotube atrophy is blunted in murine muscle cells lacking myostatin. Images of myotube cell cultures from wild-type and myostatin -/- mice treated with $200 \mu \mathrm{M}$ of $\mathrm{CoCl}_{2}$ are shown.

B) Myotube diameter of myostatin deficient cells is increased and resistant to $\mathrm{CoCl}_{2}$ treatment. Myotube diameter was measured at day 3 of differentiation in cell cultures from wild-type and myostatin -/- mice. Histograms are means \pm s.e.m. for at least three assays. 
Independent cell cultures were obtained from at least five mice of the indicated genotype. The two-way ANOVA revealed a significant $\mathrm{CoCl}_{2}$ effect $(\mathrm{P}<0.001)$. The second main effect was a significant myostatin expression effect $(\mathrm{P}<0.001)$; the myostatin $-/-$ muscles being significantly less sensitive to $\mathrm{CoCl}_{2}$ treatment than myostatin $+/+$ muscles. No significant interaction effect could be detected between $\mathrm{CoCl}_{2}$ and myostatin factors $(\mathrm{P}>0.05)$ indicating that the difference in treatment response between $-/-$ and $+/+$ myostatin was not different among the $\mathrm{CoCl}_{2}$ doses. \$, $\mathrm{P}<0.05$ versus untreated wild type; *, $\mathrm{P}<0.05$ versus untreated wild type. Scale bar, $20 \mu \mathrm{m}$. At least 300 myotubes were analysed.

\section{Fig. 7. Myostatin restored $\mathrm{CoCl}_{2}$-induced atrophy}

A) Myostatin induces CAGA reporter activity in murine muscle cells. Primary murine myoblasts were transiently transfected with CAGA-luciferase reporter construct. RL-tk-luc plasmid was included in transfections as internal control for transfection efficiency. At $24 \mathrm{~h}$ after transfection, cells were grown in differentiating medium and treated or not with recombinant myostatin $(1 \mu \mathrm{g} / \mathrm{ml})$ for $24 \mathrm{~h}$ before harvesting. Luciferase activities were normalized with pRL-tk luciferase activity and induction of transcription was calculated from values from -treated cells over values from vehicle-treated cells. Values are significant at * $\mathrm{P}<0.05$ as indicated in the figure. The bars represent the mean \pm SEM of three independent experiments performed in triplicate.

B) Myostatin restores the atrophic effect of $\mathrm{CoCl}_{2}$ in murine myostatin deficient myotubes.

Myotubes were treated at day 2 after fusion with either or both of $\mathrm{CoCl}_{2}(200 \mu \mathrm{M})$ or recombinant myostatin (Mstn) $(1 \mu \mathrm{g} / \mathrm{ml})$, and analysed at day 3 of differentiation.

C) Quantification of myotube diameter in presence or absence of recombinant myostatin.

Histograms are means for at least 3 assays. *, $\mathrm{P}<0.05$ versus untreated wild type myotubes; $\$$, 
$\mathrm{P}<0.05$ versus untreated myostatin $-/-$ myotubes. Scale bar, $20 \mu \mathrm{m}$. At least 300 myotubes were analysed. 
Table 1 : Body weights and muscle weights in normoxic (N), normoxic pair fed (Npf) and hypoxic $(\mathrm{H})$ rats

\begin{tabular}{|l|c|c|c|}
\hline & $\begin{array}{c}\mathrm{N} \\
(\mathrm{n}=10)\end{array}$ & $\begin{array}{c}\text { Npf } \\
(\mathrm{n}=10)\end{array}$ & $\begin{array}{c}\text { H } \\
(\mathrm{n}=10)\end{array}$ \\
\hline Body weight, g & $445 \pm 17$ & $386 \pm 10^{\star}$ & $378 \pm 12^{\star}$ \\
Gas, mg & $1743 \pm 57$ & $996 \pm 87^{\star \star}$ & $947 \pm 178^{\star \star}$ \\
Gas/body weight, (mg/g)x100 & $420 \pm 25$ & $261 \pm 15^{\star \star}$ & $249 \pm 33^{\star \star, \ddagger}$ \\
Gas Protein content (mg/muscle) & $131 \pm 5$ & $95 \pm 11$ & $78 \pm 5^{\star \star}$ \\
Sol, mg & $168 \pm 23$ & $152 \pm 19$ & $128 \pm 8^{\star, \pm}$ \\
Sol/body weight, (mg/g)x100 & $45 \pm 9$ & $32 \pm 4$ & $30 \pm 2^{\star}$ \\
Sol Protein content (mg/muscle) & $12 \pm 3$ & $9 \pm 1$ & $8 \pm 1$ \\
& & & \\
\hline
\end{tabular}


Table 2: Subject characteristics

Characteristics

Control Subjects

$(\mathrm{n}=5)$

Patients with COPD

Age, yr

$62 \pm 1$

$(\mathrm{n}=10)$

Body composition

Weight, $\mathrm{kg}$

BMI, $\mathrm{kg} / \mathrm{m} 2$

$78 \pm 2$

26

FFM kg

$56 \pm 2$

$64 \pm 3$

FFMI, $\mathrm{kg} / \mathrm{m} 2$

19

$70 \pm 4$

$24 \pm 1$

$53 \pm 2$

$18 \pm 1$

FM kg

$21 \pm 2$

$19 \pm 3$

\section{Lung function parameters}

FEV1\% pred

FEV1/FVC \%

$108 \pm 3$

$77 \pm 1$

$37 \pm 3^{* * * *}$

$41 \pm 3 * * *$

Peripheral muscle function parameters

Quadriceps endurance time, $s$

$673 \pm 112$

$284 \pm 31 *$

MVC, kg

$24 \pm 1$

$20 \pm 2$

6-MWD

$574 \pm 28$

$383 \pm 43 * * *$

Definitions and abbreviations: $\mathrm{BMI}=$ Body mass index $; \mathrm{FFM}=$ fat-free mass $; \mathrm{FFMI}=$ fat free mass index; FEV1 $=$ forced expiratory volume in one second; $\%$ pred $=\%$ predicted, $\mathrm{FVC}=$ forced vital capacity; $\mathrm{MVC}=$ maximal voluntary contraction, 6-MWD = 6-minute walk distance. Data are presented as mean \pm SEM. $* \mathrm{P}<0.05 ; * * * \mathrm{P}<0.001$ 


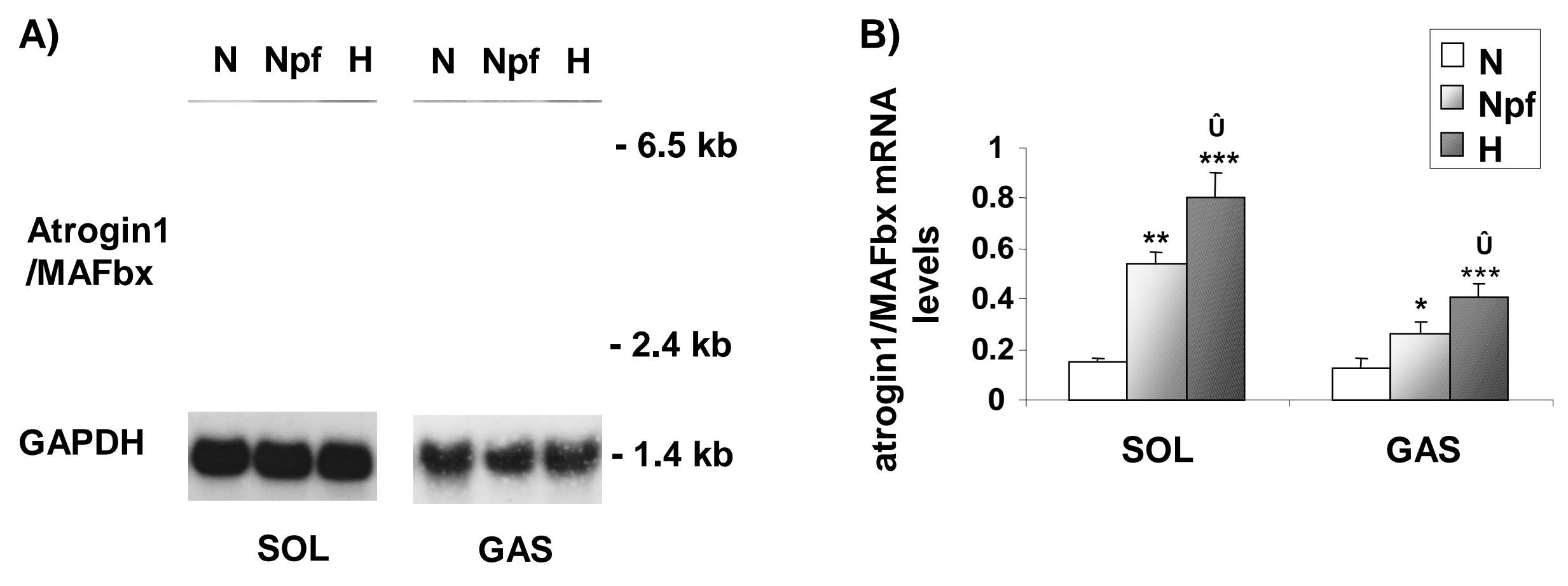




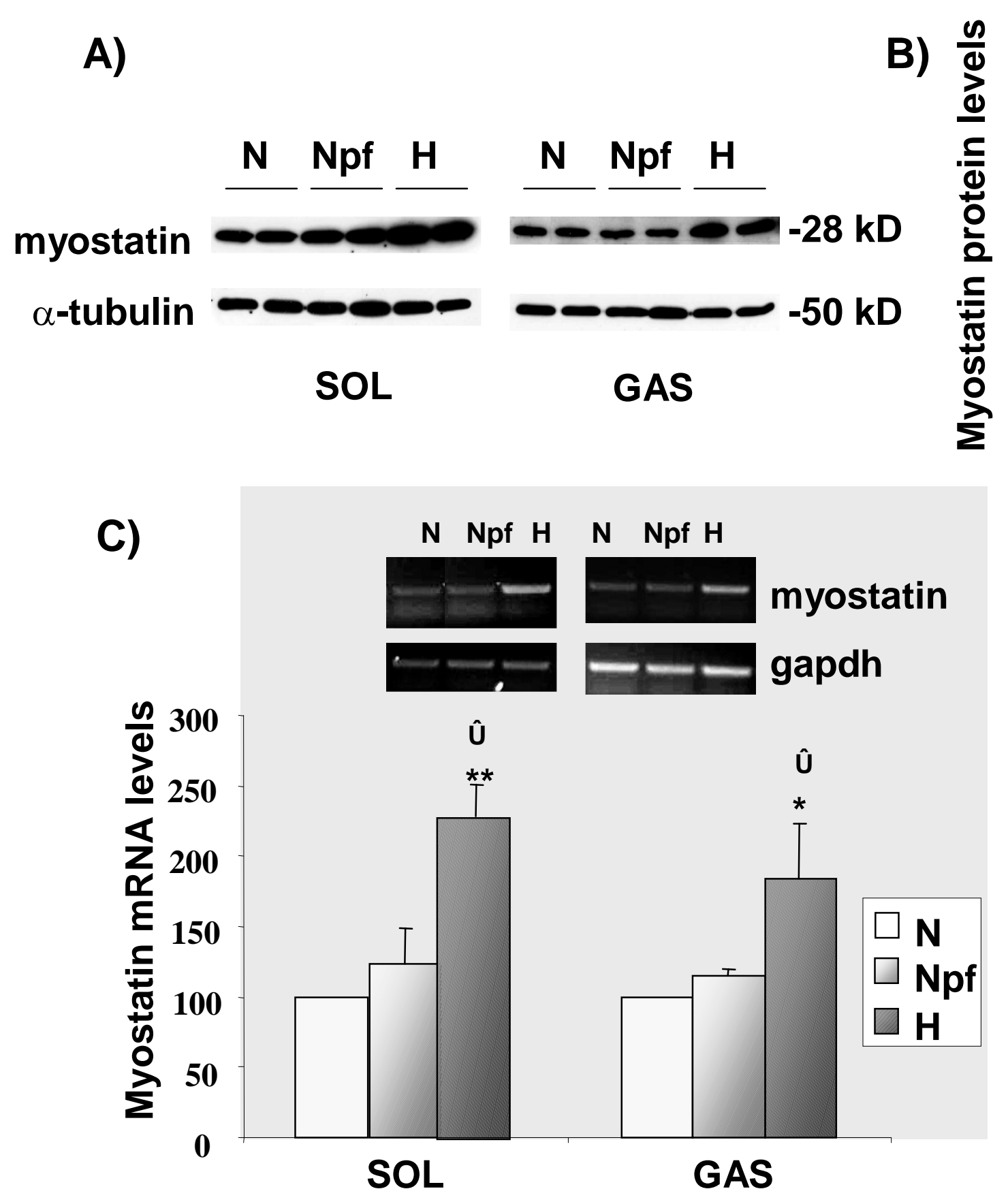

Figure 2: Hayot et al. 
A)

C)
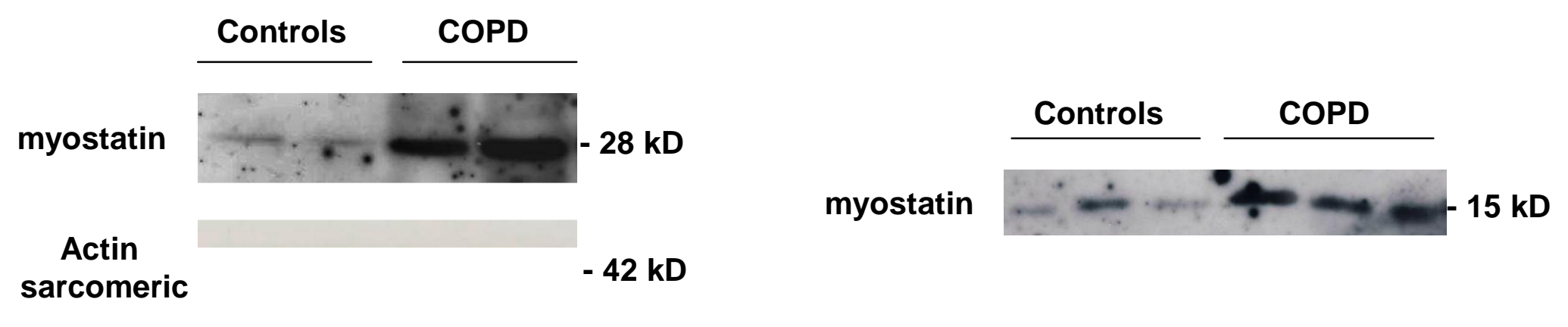

B)

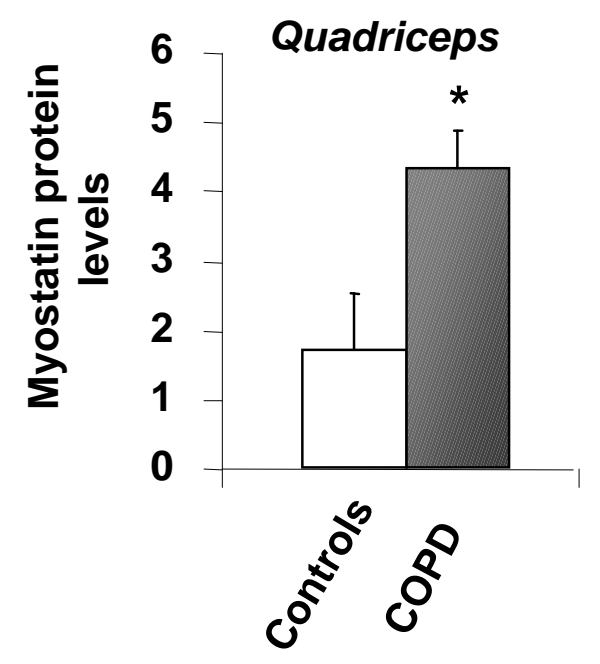

D)

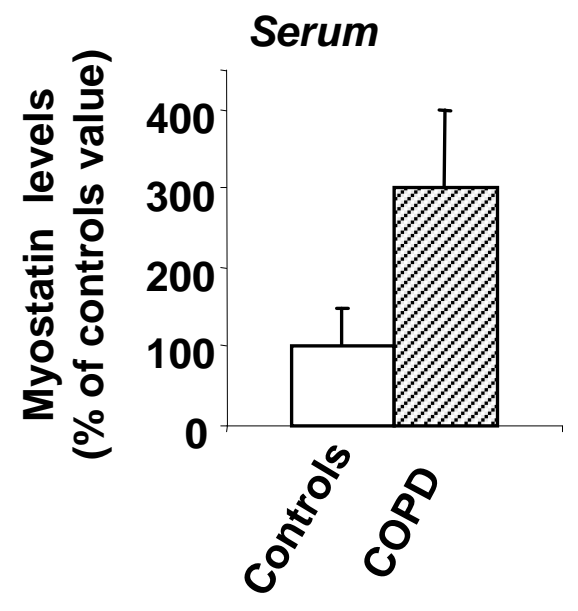

Figure 3: Hayot et al. 
A)
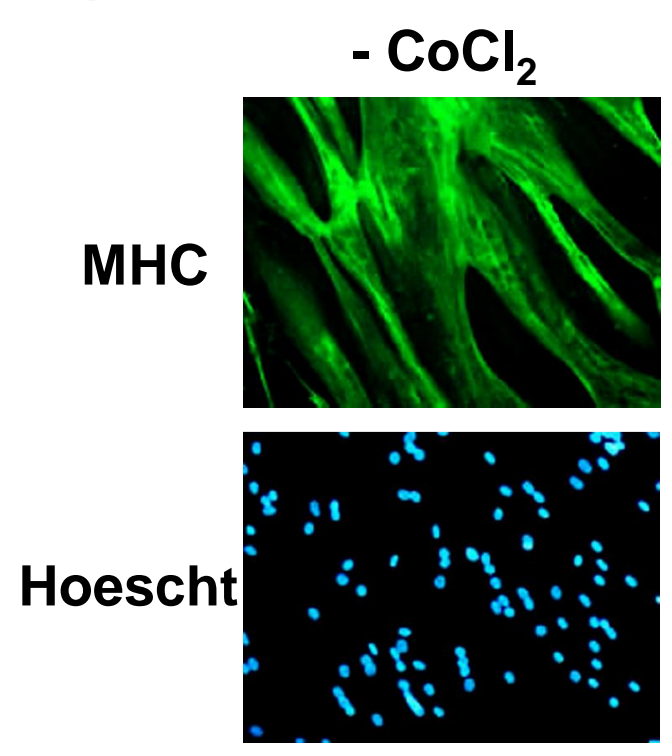

Human myotube

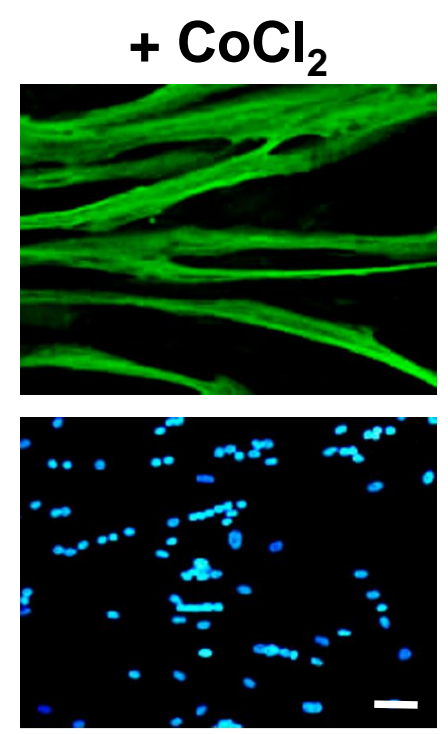

B)

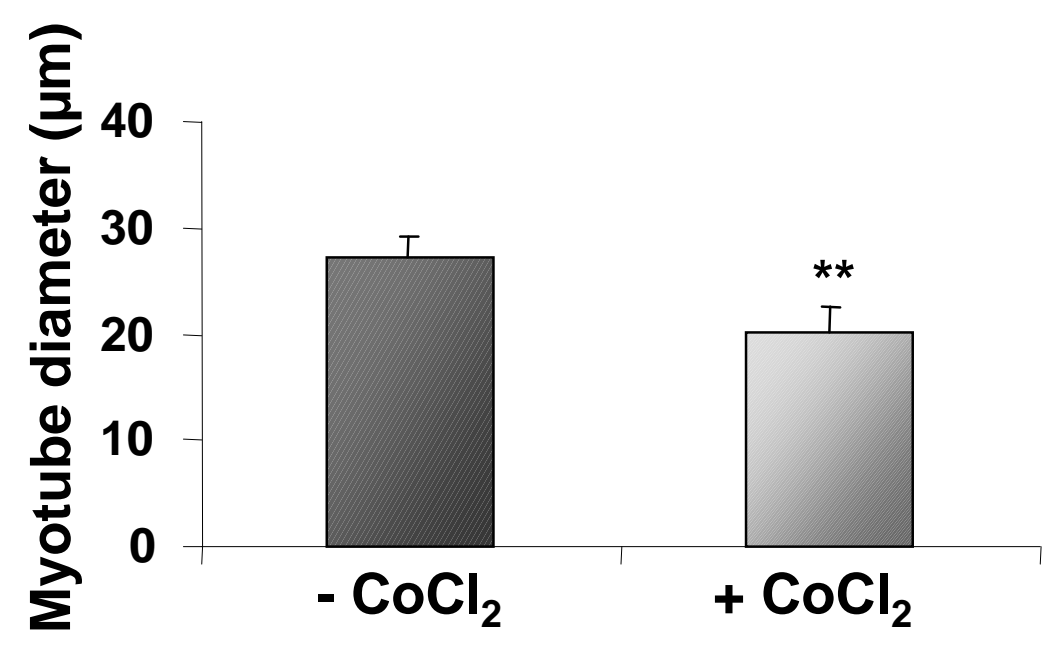

C)

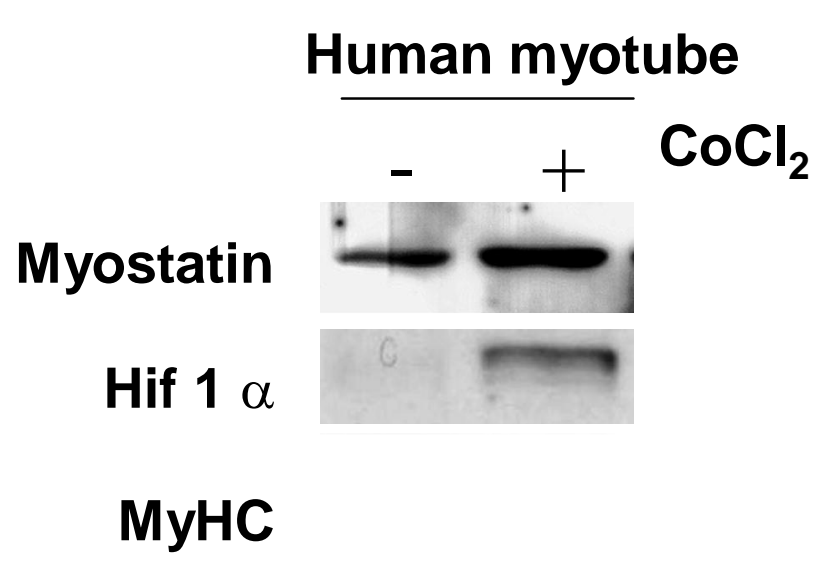

Tubulin

Figure 4: Hayot et al. 
A)

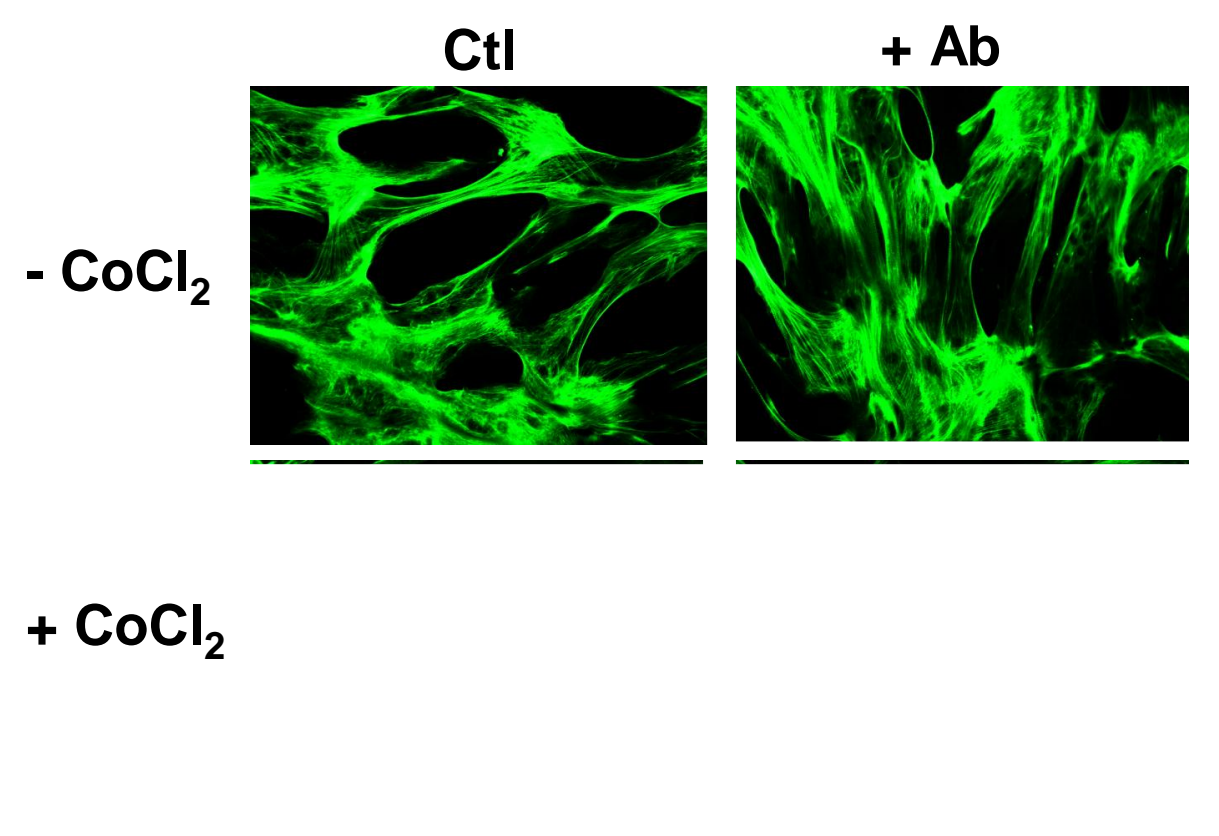

B)

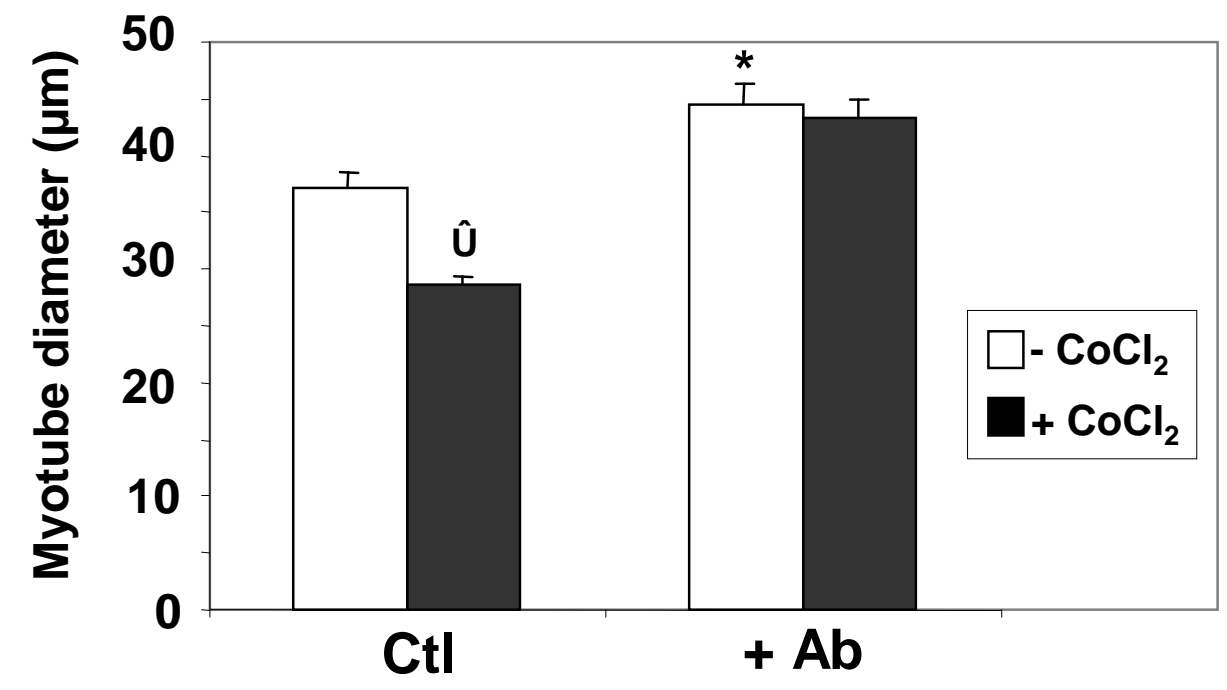

Figure 5: Hayot et al. 
A)

$+\mathrm{CoCl}_{2}$

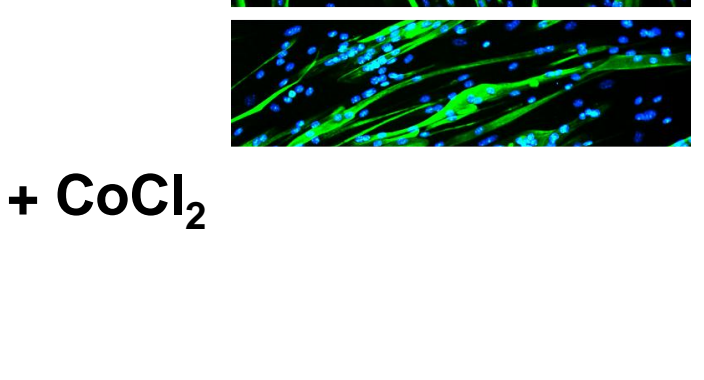

$+/+$

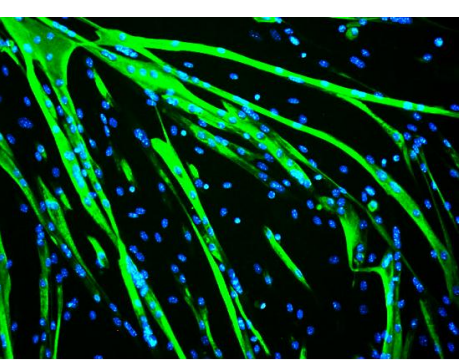

$-\mathrm{CoCl}_{2}$
B)

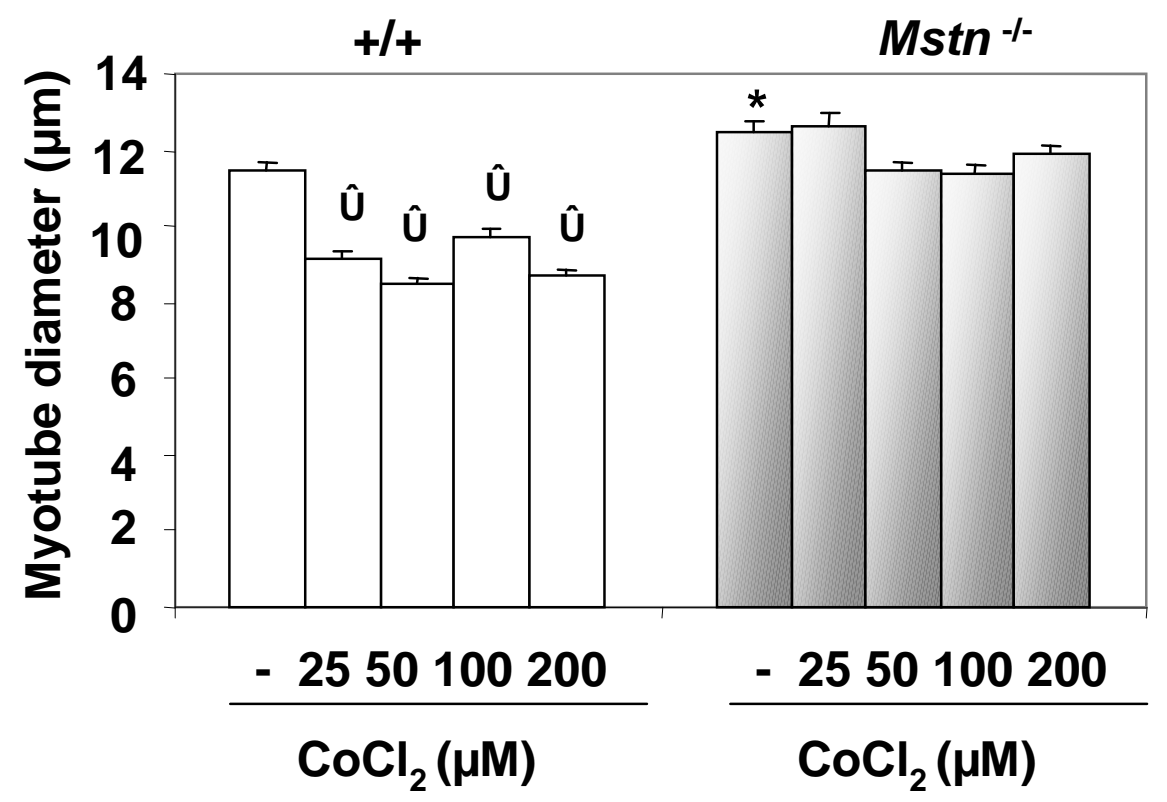

Figure 6: Hayot et al. 
A)

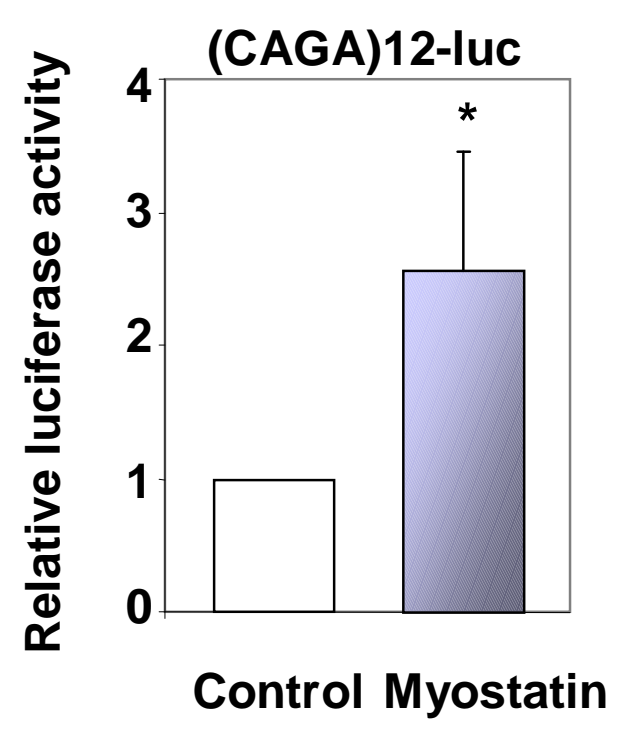

Figure 7: Hayot et al.

B)

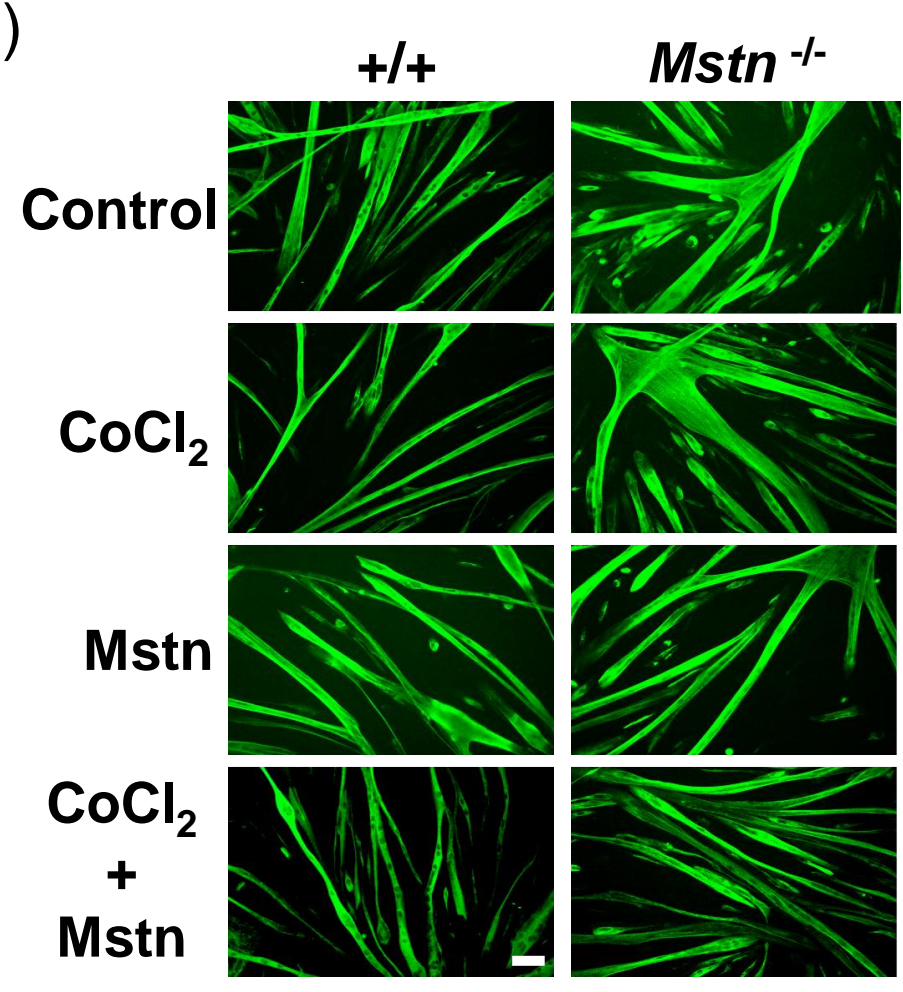

C)

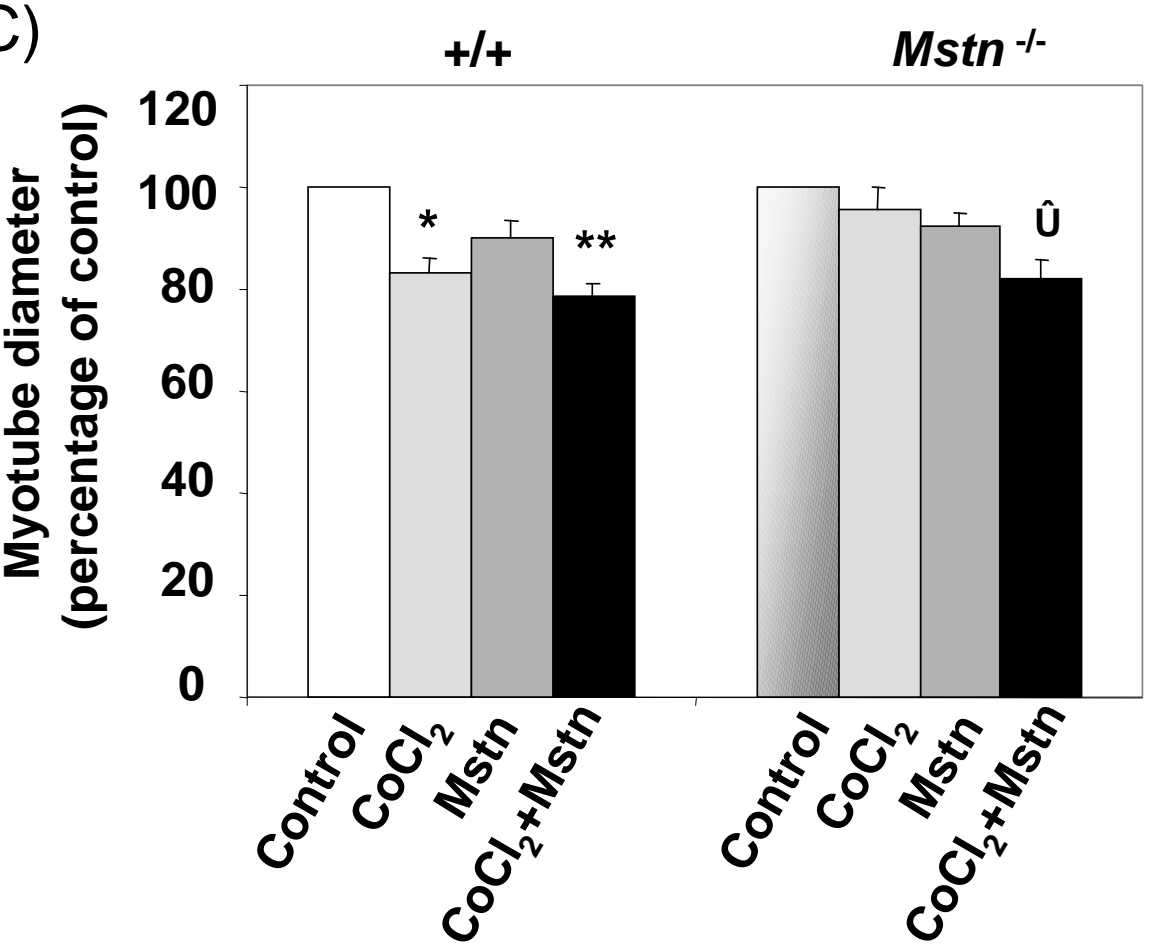

